IZA DP No. 4762

Does Conflict Disrupt Growth?

Evidence of the Relationship between Political Instability and National Economic Performance

Solomon W. Polachek

Daria Sevastianova

February 2010 


\title{
Does Conflict Disrupt Growth? Evidence of the Relationship between Political Instability and National Economic Performance
}

\author{
Solomon W. Polachek \\ State University of New York at Binghamton \\ and IZA \\ Daria Sevastianova \\ University of Southern Indiana
}
Discussion Paper No. 4762
February 2010

\author{
IZA \\ P.O. Box 7240 \\ 53072 Bonn \\ Germany \\ Phone: +49-228-3894-0 \\ Fax: +49-228-3894-180 \\ E-mail: iza@iza.org
}

Any opinions expressed here are those of the author(s) and not those of IZA. Research published in this series may include views on policy, but the institute itself takes no institutional policy positions.

The Institute for the Study of Labor (IZA) in Bonn is a local and virtual international research center and a place of communication between science, politics and business. IZA is an independent nonprofit organization supported by Deutsche Post Foundation. The center is associated with the University of Bonn and offers a stimulating research environment through its international network, workshops and conferences, data service, project support, research visits and doctoral program. IZA engages in (i) original and internationally competitive research in all fields of labor economics, (ii) development of policy concepts, and (iii) dissemination of research results and concepts to the interested public.

IZA Discussion Papers often represent preliminary work and are circulated to encourage discussion. Citation of such a paper should account for its provisional character. A revised version may be available directly from the author. 
IZA Discussion Paper No. 4762

February 2010

\begin{abstract}
Does Conflict Disrupt Growth? Evidence of the Relationship
between Political Instability and National Economic Performance*

Current empirical growth models limit the determinants of country growth to geographic, economic, and institutional variables. This study draws on conflict variables from the Correlates of War (COW) project to ask a critical question: How do different types of conflict affect country growth rates? It finds that wars slow the economy. Estimates indicate that civil war reduces annual growth by .01 to .13 percentage points, and high-intensity interstate conflict reduces annual growth by .18 to 2.77 percentage points. On the other hand, lowintensity conflict slows growth much less than high-intensity conflict, and may slightly increase it. The detrimental effect of conflict on growth is intensified when examining nondemocracies, low income countries, and countries in Africa.
\end{abstract}

JEL Classification: $\quad$ C2, O1, O47, O57, P47, P52

Keywords: economic growth, war, conflict

Corresponding author:

Solomon W. Polachek

Department of Economics

and Department of Political Science

State University of New York at Binghamton

Binghamton, New York 13902-6000

USA

E-mail: polachek@binghamton.edu

\footnotetext{
* We thank Christopher Hanes, John Lott, David Clark, Luis Locay, Michael Intriligator, and Carlos Seiglie for their helpful comments and suggestions. Versions of this paper were presented at the Peace Science Society Conference (Columbia, SC, November 2007), the American Economics Association Conference (New Orleans, LA, January 2008), International Studies Association Conference (San Francisco, CA, March 2008), and Eastern Economic Association Conference (New York, NY 2009).
} 


\section{Does Conflict Disrupt Growth? Evidence of the Relationship between Political Instability and National Economic Performance}

From 1899 to 2001, there have been over 200 wars throughout the world. In 2007 alone, there were 14 active armed conflicts. ${ }^{2}$ One important question is how wars affect a country's economic well-being. Indeed the depletion of resources during wars may be one reason why some countries fail to sustain adequate economic growth. Because economic growth affects a population's well-being, this question concerning how war relates to growth is important from a policy perspective. Overall economic theory is ambiguous about the relationship between war and economic growth. On the one hand, war destroys capital and utilizes manpower. On the other, war mobilizes the workforce, increasing effort and enhancing productivity.

This paper utilizes various measures of interstate and intrastate conflict from the political science literature to ascertain how a nation's involvement in international and civil wars relates to its economic growth. To get at these measures the paper utilizes techniques from the economics growth theory literature, which at least since the 1990s turned empirical. Our innovations over past research are to use far longer time-series data on country growth, to incorporate detailed information on both domestic and international conflict, to include conflict duration and severity, to examine various country subsamples, and to adopt fixed-effects estimation techniques.

Empirical growth models estimate how changes in a country's physical and human capital as well as technology enhance GNP per capita. For example, Barro (1991) and Sachs and Warner (1997) find that a tropical geography and an abundance of natural resources are negatively related to growth. ${ }^{3}$ Trade liberalization, democracy, government stability, and a legal system that strongly protects private property rights enhance

\footnotetext{
${ }^{2}$ SIPRI Yearbook 2008.

3 Mehlum, H. et. al (2006) argue that institutions are a key determinant of long run economic growth.
} 
growth. ${ }^{4}$ One particular innovation of this literature was to examine how government and economic structure affect growth. As such, Londregan and Poole (1990), Barro (1991), Barro and Lee (1993), Easterly et al. (1993), Easterly and Rebelo (1993), Alesina and Perotti (1996), Persson and Tabellini (2006) find that government and social instability and political violence often negatively affect growth.

At about the same time the growth literature evolved, political scientists began to apply quantitative methods to classify and measure political interactions including interstate and intrastate wars. Early compilations of wars and their associated casualties (Wright (1942) and Richardson (1960)) code wars that have taken place well before accurate national accounts data were available to assess their economic impact. Nowadays there are two main ongoing compilations of war that do not have this deficiency because they are more current (1) Uppsala University Data on Armed Conflict compiled by The Centre for the Study of Civil War at the International Peace Research Institute, Oslo (PRIO) and Uppsala Conflict Data Program (UCDP) at the Department of Peace and Conflict Research, and (2) the Correlates of War (COW) project originally compiled by J. David Singer at the University of Michigan. These data are periodically updated, the latter by the Peace Science Society (PSS), and contain detailed information on fatalities and duration of both international and civil wars for the years 1970-2000, which include and go beyond the years analyzed by Barro and Sachs-Warner in their analyses of growth.

At least from a policy perspective, it is important to measure how such fighting within and between countries affects a country's economic growth. Because wars have not stopped, the relevance of this question persists. The estimates obtained in this paper hopefully can be used to assess how wars could affect future world growth.

We find that interstate conflict decreases economic growth by .18 to 2.77 percentage points, while intrastate conflict decreases economic growth by .01 to .13

\footnotetext{
${ }^{4}$ Some of the recent literature on democracy finds the link between regime type, income, and religion. Specifically, Borooah, and Paldam, (2007) find that poverty, Communism, and Muslim culture are the main barriers to democratic governance.
} 
percentage points. Such negative growth intensifies with conflict severity. Furthermore, conflict reduces economic growth the most in the short run, whereas in the long run economies recover from the adverse effects of wars. Our results show that poor countries engage in civil wars, while rich countries engage in international wars. Civil wars hurt economic prospects of all affected countries, and are especially detrimental to economic growth in non-democracies. International wars reduce growth most in African and lowincome countries. Interestingly, international conflict waged by the OPEC members augments rather than reduces growth. Overall, the impact of conflict varies with conflict intensity, as well as by country type, wealth, and polity.

We approach our analysis in five steps. First, we replicate and extend the Barro growth model with updated Sachs-Warner variables calculated from the Penn World Tables (Version 6.1 dated 2000), the World Development Indicators (2005), and the Political Risk Services Group IRIS-3 data. Second, we introduce Correlates of War (COW) measures of interstate and intrastate conflict by utilizing both duration and severity measures. Third, we examine smaller time intervals. Fourth, we divide countries by region, polity, and income level to examine the effects of wars separately in each of those groups. Finally, fifth, we corroborate our results using an alternative empirical specification.

\section{Brief Literature Review}

Robert Solow's (1957) path breaking innovation was to couch economic growth within a neoclassical framework. This framework significantly advanced the prior more rigid Harrod-Domar fixed proportions model developed in the 1930s, and led to influential empirical work by Barro (1991), Sachs-Warner $(1995,1997)$ and others 5 .

Though not the main focus, Barro (1991) incorporates two measures of political instability. Both of these, the number of revolutions and or coups per year (see Barro

\footnotetext{
${ }^{5}$ Most prominent work in growth literature includes done by Barro $(1989,1991)$, Barro and Sala-i-Martin (1992, 1995), Barro and Lee (1993), Mankiw, Romer, Weil (1992), Sachs and Warner (1995, 1997), and Hall and Jones(1997,1999).
} 
andWolf 1989) as well as the number of political assassinations per year per million population negatively affects growth. ${ }^{6}$ Barro's interpretation is that both of these variables distort property rights, and thereby hamper investment and decrease growth. Barro and Lee (1993) subsequently confirm that revolutions inhibit growth as do Knack and Keefer (1995) and Easterly and Levine (1997). Alesina et al. (1996) similarly obtained a negative coefficient on the probability of government change in a growth regression. Furthermore, Alesina and Perotti (1996) confirmed that political violence (assassinations, deaths from political violence, coups, and a dictatorship dummy) reduces growth. In recent line of literature, Jong-A-Pin (2009) finds only the instability of the political regime has a robust and significant negative effect on economic growth. In contrast Barro and Lee (1993) found no significant relationship between political violence measured by a war dummy and growth. Similarly, Easterly et al. (1993) and Easterly and Rebelo (1993) established that assassinations, coups, revolutions, and war casualties variables have no significant effect on economic growth. ${ }^{7}$ In addition, a metastudy by Brunetti (1997), indicates most analyses yield a negative but insignificant political violence growth relationship. In sum, these studies lack robustness regarding the effects of political instability.

More recently, some studies adopt growth theory to examine the economic effects of civil wars, but to date none to our knowledge adequately incorporate international wars. This literature points to various theoretical reasons why civil wars are detrimental to the steady state long run income per capita growth rate. ${ }^{8}$ These include the effects of declines in human and physical capital, the growth of labor, and reductions in trade and FDI. War also creates uncertainty and disrupts daily market activity. In long run models, studies find weak effects of civil wars on growth. Models of civil wars using spatial econometric techniques to get at spillovers better capture the destructive influence on both home and neighboring territories. Because these effects are better captured with 5year intervals, Murdoch and Sandler (2004) conclude that the devastating effects of civil

\footnotetext{
${ }^{6}$ Barro (1991) obtaines hiw two measures from Banks (1979). Some studies also used political freedom and civil liberties measures from Gastil (1989).

${ }^{7}$ Easterly and Rebelo (1993) find a negative coefficient on casualties only when marginal tax rates are included in the specification.

${ }^{8}$ Sambanis (2001), Collier and Sambanis (2002), Murdoch and Sandler (2002, 2004).
} 
wars are generally short lived, but they do not examine these duration effects for interstate wars. In addition, Collier and Sambanis (2002) find that civil wars are rare in democracies, as most democracies also happen to be high-income countries with low civil war incidence. Hillman (2009, chapter 3) explains the different propensities democracies and autocracies engage in war by the costs of war for the general population and the personal benefits for autocratic rulers. While these studies recognize the complexity of causes of civil war, which possibly helps explain the difference in their economic effects, it is beyond the scope of this paper to distinguish between various types of civil war, such as war based on ethno-linguistic division vs. rent-seeking and resource extraction, for example. The paper in part accounts for that by examining regional differences, as those frequently act as a proxy for civil war type.

Contemporary growth studies have also given much attention to conflict in SubSaharan Africa. For example, Merrouche (2008) argues that de-mining programs in Mozambique have generated positive economic effects. Another line of literature stresses the importance of neighborhood effects in Africa (including Brock and Durlauf, 2003). Research on the effects of ethnic heterogeneity on civil war in Africa has also shed light on the mechanisms underlying war incidence. ${ }^{9}$ Finally, current research has addressed the question of conflict trap. In his book The Bottom Billion, Collier writes about the civil war trap, where past civil war increases the probability of future civil war. In such environments, negative association between civil war and growth is self-perpetuating.

A number of deficiencies remain in assessing these studies. First, none of these studies comprehensively examine the effect of international wars on growth. Second, most analyses of the effects of conflict on growth stop at or before the 1990s. Third, not all studies use actual war data. Those that do fail to take account of war severity. Fourth, with the exception of several studies pertaining to the effects of civil wars, most use 30year time durations. But as Murdoch and Sandler (2004) show, the effects of civil wars can be short-lived, implying the necessity to evaluate the time duration over which growth can be affected. Fifth, virtually all the studies that measure the effects of conflict

\footnotetext{
${ }^{9}$ Alesina, et al. (2003\&2006), Montalvo and Reynal-Querol (2005).
} 
on growth fail to examine interactive effects. They look at how conflict relates to growth holding constant such variables as region, polity and country income, but not whether wars have a more detrimental effect in Africa or America, or whether democracies suffer more than autocracies. Finally, each study adopts the Barro (1991) and Sachs-Warner (1995, 1997) specification without checking robustness using alternative statistical specifications. As already mentioned in the last section, we overcome these shortcomings first by utilizing data through 2000; second, by using detailed interstate and intrastate war data encompassing both war incidence and severity; third, by analyzing various time durations of the effects of wars from one to thirty years; fourth, by stratifying by region, polity, and country income to get at wars' interactive effects; and finally fifth, by using an alternative statistical specification to corroborate our results. Unlike the studies which utilize cross-sectional Barro style regressions, we incorporate statistical models making use of within country fixed effects.

The mechanism through which conflict operates is not a subject of this paper. However, the literature contains a number of themes. For example, both Persson and Svensson (1989) and Tabellini and Alesina (1989) argue that governments of politically unstable or violent countries are more prone to rent-seeking, and therefore adopt suboptimal policies on taxation, as well as face higher debt and government consumption to GDP ratios. Research published in Forty Years of Research on Rent Seeking, Volume II, Applications: Rent Seeking in Practice, Congleton, et. al (2008) addresses the linkage between rent-seeking and economic growth and development. As rent-seeking is typically considered a deadweight loss to society, conflict which encourages rent-seeking would also be associated with fewer property rights and a poorer rule of law. Fewer property rights would decrease growth rates and cause a lower steady state income level, thereby reducing long run growth prospects. ${ }^{10}$ As North $(1990$, p.54) puts it, "the inability of societies to develop effective, low-cost enforcement of contracts is the most important source of both historical stagnation and contemporary underdevelopment in the Third World." Hillman (2004) shows how absence of the rule of law allows the strong to

\footnotetext{
${ }^{10}$ Persson and Svensson (1989) and Tabellini and Alesina (1989).
} 
exploit the weak and how the disincentives confronting the weak underlie development failure.

Similarly, uncertainty about property rights brought about by conflict can distort investment and saving incentives. This research reveals that in the face of uncertainty and weak property rights actors defer making investments especially when they cannot completely recover their sunk costs. These in effect create a tax on investment and hamper long term growth. ${ }^{11}$ In addition, instability impedes savings incentives and therefore lowers economic growth. ${ }^{12}$ Also, if wars slow political and economic reforms needed in an economy, long run income growth can be weakened by the economy's failure to adapt to change. ${ }^{13}$

Another recent line of empirical growth literature examines how conflict affects the allocation of international aid by donors. For example, Chauvet (2003) argues that while violent instability attracts foreign aid, social instability discourages it. Therefore, to the extent that aid stimulates economic growth, conflict might affect aid allocation decisions and therefore growth rates in aid recipient countries. ${ }^{14}$

In addition, economic research paid much attention to the conflict-trade relationship. Notably, Polachek $(1980,1997)$ argues that trade reduces conflict. In this context, simultaneous equations models do not alter this finding, but actually corroborate it. While we acknowledge the importance of inclusion of trade in modeling the conflictgrowth relationship, a simultaneous equations approach is beyond the scope of the current study, although it does pose a productive future venue in the study of conflict. Authors also acknowledge that trade might have a differential impact on the economy depending on the type of country: for example, in the Southeast Asian country grouping much of the rapid growth has been propelled by increased trade and FDI, unlike Latin American countries who experienced a smaller rate of trade growth; OPEC countries

\footnotetext{
${ }^{11}$ Dixit and Pindyck (1994); Aizenman and Marion (1993); Alesina and Perotti (1996).

${ }^{12}$ Venieris and Gupta (1986).

${ }_{14}^{13}$ Dollar and Svensson (2000).

${ }^{14}$ In research on allocation of foreign aid, a meta-study by Doucouliagos, H. and M. Paldam (2008) establishes that neither good policy nor aid itself are significant factors.
} 
have traded primarily in oil exports, and African countries have remained heavily dependent on primary product exports.

\section{The Model}

In line with Mankiw, Romer, and Weil (1992) interpretation of the Solow (1957) growth accounting framework, the estimating equation is expressed as a growth rate, or the time-difference between natural logs of income per worker at the end (Yit) and starting points (Yio) of a given time period. If the speed of convergence to the steady state $y^{*}$ at time $t$ from the initial value of income is $\lambda$, then the growth rate during the transition to the steady state is expressed as:

$\ln y_{t}-\ln y_{0}=\left(1-e^{-\lambda t}\right) \ln y^{*}-\left(1-e^{-\lambda t}\right) \ln y_{0}$

based on specifying country output as a Cobb-Douglas production function and making a series of substitutions for the steady state. This yields the following estimating equation for growth of income per capita: ${ }^{15}$

$$
\begin{array}{r}
\ln y_{t}-\ln y_{0}=a+\left(1-e^{-\lambda t}\right)[\alpha /(1-\alpha-\beta)] \ln \left(s_{k}\right)+\left(1-e^{-\lambda t}\right)[\beta /(1-\alpha-\beta)] \ln \left(s_{h}\right)- \\
\left(1-e^{-\lambda t}\right)[(\alpha+\beta) /(1-\alpha-\beta)] \ln (n+g+\delta)-\left(1-e^{-\lambda t}\right) \ln y_{0}+\varepsilon,
\end{array}
$$

where $a$ is a constant; $\alpha$ and $\beta$ are the elasticities of output with respect to physical and human capital, and $1-\alpha-\beta$ is the output elasticity of effective units of labor; $\mathrm{s}_{\mathrm{k}}$ and $\mathrm{s}_{\mathrm{h}}$ denote the savings rates of physical and human capital respectively; $n$ is the rate of population growth, $g$ is the rate of technological progress, and $\delta$ is capital depreciation; and finally $\varepsilon$ is a country specific random error. The last term with lagged income shows negative coefficient, otherwise known as the convergence parameter, which signifies that given identical production functions, a country with a lower initial income level will

\footnotetext{
${ }^{15}$ Derivation of $y^{*}$ is as follows. The transition equations for human and physical capital are given by $\mathrm{dk} / \mathrm{dt}=\mathrm{s}_{\mathrm{k}} \mathrm{y}-(\mathrm{n}+\mathrm{g}+\delta) \mathrm{k}$ and $\mathrm{dh} / \mathrm{dt}=\mathrm{s}_{\mathrm{h}} \mathrm{y}-(\mathrm{n}+\mathrm{g}+\delta) \mathrm{h}$. Taking logs and substituting for the steady state values of capital (i.e. when $\mathrm{dk} / \mathrm{dt}=0$ and $\mathrm{dh} / \mathrm{dt}=0$ ) into the production function $\mathrm{Y}_{\mathrm{t}}=\mathrm{K}_{\mathrm{t}}^{\alpha} \mathrm{H}_{\mathrm{t}}^{\beta}\left(\mathrm{A}_{\mathrm{t}} \mathrm{L}_{\mathrm{t}}\right)^{1-\alpha-\beta}$, where $\alpha+\beta$ $<1$ yields the following steady state income per capita equation: $\ln \left[\mathrm{Y}_{\mathrm{t}} / \mathrm{L}_{\mathrm{t}}\right]=\ln \mathrm{A}_{0}+\mathrm{gt}+[\alpha /(1-\alpha-\beta)] \ln \left(\mathrm{s}_{\mathrm{k}}\right)+$ $[\beta /(1-\alpha-\beta)] \ln \left(\mathrm{s}_{\mathrm{h}}\right)-[(\alpha+\beta) /(1-\alpha-\beta)] \ln (\mathrm{n}+\mathrm{g}+\delta)$. If $\mathrm{A}_{0}=\mathrm{a}+\varepsilon$, where $a$ is a constant and $\varepsilon$ is a country specific shock, while ignoring $\mathrm{g}_{\mathrm{t}}$, steady state income per capita $\mathrm{y}^{*}$ will be: $\mathrm{y}^{*}=\ln [\mathrm{Y} / \mathrm{L}]=\mathrm{a}+[\alpha /(1-\alpha-\beta)] \ln \left(\mathrm{s}_{\mathrm{k}}\right)+$ $[\beta /(1-\alpha-\beta)] \ln \left(\mathrm{s}_{\mathrm{h}}\right)-[(\alpha+\beta) /(1-\alpha-\beta)] \ln (\mathrm{n}+\mathrm{g}+\delta)+\varepsilon$.
} 
grow faster. ${ }^{16}$ This term is peculiar to the growth rate equation (1), and is not observed in the steady state income level equation.

In the empirical growth literature, several specifications are used to decompose income into economic inputs. One possible specification describes the steady state level of income per capita where income in the last period is at the steady state level, while other specifications look at the growth rate of income per capita, as the economy moves from the first period to the last, which captures transition to the steady state. ${ }^{17}$ The long term framework - whether it examines the level of steady state income or the average growth rate of income over the entire period - underlies cross-sectional studies. Conversely, a panel framework considers growth rates over several shorter time durations and thus models growth in the short run. Because in such studies the notion of the steady state is absent, they are referred to as "growth regressions". In these studies, the main impact of war is the destruction of existing physical capital and the temporary reduction of human capital accumulation. The models also predict a burst of post-war growth as the economy recovers, or returns to its steady state path.

\section{The Data}

We use seven data sources: (1) Penn World Tables, (2) World Bank data, (3) Sachs and Warner data, (4) International Risk Investment Survey (IRIS) data, (5) United States Central Intelligence Agency (CIA) World Factbook data, (6) Polity IV data, and (7) Correlates of War (COW) data. We discuss the first five only briefly because they are familiar to many economists, and then concentrate on the latter two. A summary of all variables is contained in Table 1.

\footnotetext{
${ }^{17}$ The dependent variable in growth regressions is usually the average growth rate, i.e. the logarithm of the ratio of the last period income to the base period income divided by the number of years within the period. ${ }^{17}$ The dependent variable in growth regressions is usually the average growth rate, i.e. the logarithm of the ratio of the last period income to the base period income divided by the number of years within the period.
} 
The Penn World Table (PWT) provides economic time series data for 188 countries. ${ }^{18}$ Data are denominated using a common set of prices so that real quantity comparisons can be made. We use this data set to obtain information on GDP and GDP per capita. The World Development Indicators (WDI) contains more than 900 indicators on over 200 economies. The data are based on censuses and household surveys drawn in conjunction with numerous international, government, and nongovernmental organizations. Sources used are the most authoritative available, and in reporting these data the World Bank made considerable effort to standardize the information. We use the WDI to obtain information on government revenues and expenditures, primary product exports, population growth and life expectancy. The IRIS data are based on information obtained from the International Country Risk Guide. It contains statistics on corruption in government, rule of law, bureaucratic quality, ethnic tensions, repudiation of contracts by government, and risk of expropriation. We utilize data containing a ten-point index of each country's institutional quality. The CIA World Fact- book is an annual volume containing information on land, water, people, government, economy, communications, and defense forces. It began annual publication in 1981 and contains statistics on 165 nations. We utilize access to sea to update the "landlocked" variable in the replication Sachs and Warner (1997) specification, as well as information on political regime and economic policy to update the "openness to trade variable".

The Polity IV and the Correlates of War data are put together by political scientists. Polity IV was originally begun by Ted Gurr of the University of Maryland's Center for International Development and Conflict Management. It now is continued under the auspices of Monty G. Marshall and Keith Jaggers at the George Mason University's Center for Global Policy. It contains coded annual information on regime and authority characteristics for all independent states with a population greater than 500,000 over the years 1800-2004. The degree of democracy is coded on a ten-point scale as is the degree of autocracy. The combination yields a democracy score between -10 and 10 . We use this variable to stratify between democratic and non-democratic countries.

\footnotetext{
${ }^{18}$ Our sample does not include states formed upon brake-ups: for example, Yugoslavia in the 1990s or the formerly Socialist nations which joined state membership upon the break-up of the Eastern bloc. Data availability for such countries is often limited, with the time-series only beginning in the early 1990s.
} 
The Correlates of War Data began in 1963 as a compilation of wars by J. David Singer, a political scientist at the University of Michigan. The data's objective has been the systematic accumulation of information related to wars. The war data were first published in Singer and Small (1972). In the late 1990s, the compilation was transferred to the Peace Science Society (PSS) at the Pennsylvania State University. Currently, the various parts of the COW data accumulation project are hosted by separate institutions that maintain and update individual datasets. ${ }^{19}$ The data set contains information from 1816 to the present on many attributes of international politics, particularly wars and militarized disputes, as well as information on national capabilities. We utilize the war data as well as the militarized interstate dispute data. The war data contain the following information for each war: states involved, dates, duration, deaths, result, initiator state, area where the event occurred. A war is a militarized dispute with at least 1,000 battle deaths per year. The militarized interstate dispute (MIDs) data documents instances not requiring 1,000 battle deaths, when one state threatened, displayed, or used force against another in 18162001. As with wars, the data report the states involved, the dates of each MID, and the duration. $^{20}$

A brief examination of data suggests, the relationship between conflict and per capita GDP is not straightforward. Figure 1 graphs annual real GDP per capita (measured in logs) over the 1970-2000 time period for sixteen representative countries. The shaded regions mark periods of war. These can be international interstate wars (beige), domestic intrastate wars (green), militarized interstate disputes short of war (bright yellow), or some combination, of which there are four possibilities: international wars and lower MIDs (blue); international wars and civil wars (pink); lower MIDs and civil wars (grey); international wars, lower MIDs, and civil wars (dark yellow). The un-shaded white portion denotes peaceful years with zero conflict.

The examination of dyads involved in conflict reveals no particular regularities. For example, one might suspect that such country pairings - especially in the post-WWII

\footnotetext{
${ }^{19}$ Project History online: http://www.correlatesofwar.org/

${ }^{20}$ The COW data enable us to discern not only between varying levels of conflict intensity, but to also clearly establish the boundaries/succession of such events.
} 
period - might involve a high-income and a low-income country engaged in international strife. War summary statistics provided by the COW project indicate that only about a third of dyads involved in international war after WWII were those where a rich country fought a poor country, i.e. a substantial portion of international conflict, predominantly in Africa and Latin America, is actually between low-income countries. ${ }^{21}$

No pattern emerges regarding whether one type conflict precedes or follows another. Nor is it the case that the duration of one type conflict is related to the duration of another. An increase in low-level conflict is not necessarily accompanied by an increase in either civil or international wars. To see this, Table 2 correlates the number of years a nation engages in each type conflict. For the most part, the correlation coefficients are negative. They are more negative the shorter the time interval, implying that nations are less involved in both inter- and intrastate conflicts within short time periods.

Figure 1 also shows that neither international wars nor civil wars necessarily reduce per capita income, and in fact can temporarily raise it. Similarly, in several instances low-intensity conflict is associated with a rise in per capita income. Moreover, it is not clear that one type of conflict need necessary precede or follow another. In Rwanda, India, and Angola, for instance, low-level MIDs precede wars; but civil war in Burundi precedes low-level MIDs. There are also several instances when low-intensity conflict both precedes and follows wars, as in Chad, Uganda, and Nicaragua. On many graphs, one can identify a decline in real income per capita preceding the onset of war, and one can identify a period of recovery marked by per capita GDP growth following a war. Examples of this would be the civil wars in Angola, Iran, Uganda, El Salvador, and Chad. During war the per capita GDP appears to decline, but not necessarily so, as evident in the examples of Angola, Iran, Israel, and Syria. For this reason a more detailed multivariate approach is warranted.

21 Another interesting question is whether the relationship between conflict and growth depends on a nation's winner or loser status in inter- or intra-state fighting. Although this paper does not incorporate such a distinction, it does present interest as a future research venue. 


\section{Replication and Extension of the Sachs-Warner Model}

Sachs and Warner (1997) examine growth from 1970-1990 by adapting the following equation:

$$
\left(\ln Y_{1990}-\ln Y_{1971}\right)_{i}=\beta_{0}+\beta_{1} \ln Y_{1970 \mathrm{i}}+\boldsymbol{\beta}_{2}{ }_{2} Z_{\mathrm{i}}+\phi \mathrm{C}_{\mathrm{i}}+\varepsilon_{\mathrm{i}}
$$

The dependent variable is the average growth rate measured as real GDP per worker over the entire period (normalized to annual rates by dividing by twenty, the number of years the data span). The independent variables are initial GDP per economically active population in 1970, openness to trade (using the Sachs and Warner (1995) openness index, which accounts for both the volume of trade measured as the share of exports and imports in GDP, and also for whether a country was under a socialist regime and engaged in protectionism), an interaction variable for openness and initial income, the fraction of the territory in the tropics, a landlocked dummy, central government budget balance, institutional quality index, growth of the economically active population, the share of primary product exports in GDP, the average life expectancy, and its square; and finally $\mathrm{C}_{\mathrm{i}}$ is the conflict variable measuring duration or severity of international and civil wars. The unit of observation is a country denoted by $i$. To anchor our results to what has already been done, we begin by replicating Sachs and Warner (1997) using a data set extended to 2000 and then extending this replication further by adding war data.

The results are given in Table 3. The initial column contains the Sachs and Warner 1970-1990 results. Column (1) is our replication using 1970-2000 data. As can be seen the results are very similar to Sachs and Warner (1997). Columns (2) and (3) add measures for interstate and intrastate wars. Adding data on wars does not change the previous coefficients, but we find little effect of wars on growth, whether measured as the proportion of years at war (rows 10-12), or battle deaths (rows 13-14). As will be illustrated in the next section, examining growth over the entire 1970-2000 time period might camouflage the effect of war, because the approach does not account for the particular dates wars are fought within the thirty-year period. Possibly the negative effects of a war fought late within the three decades (for example in the 1990s) might be 
more important than a war fought early within the three decades, especially if the effects of an earlier war dissipate when measured over the thirty-year time span. The Sachs and Warner method does not take such time aspects into account.

\section{Estimation Issues}

There are two issues regarding empirical estimation. First is to discern short-run and long-run effects of wars. For this, we break up our observations on each country into shorter intervals within the 1970-2000 time interval used by Sachs and Warner (1997). In doing so, we use five-year time periods (1971-1975, 1976-1980, 1981-1985, etc.), then we use two year time intervals (1971-1972, 1973-4, etc.), and finally one-year intervals. As will be explained below, in each case we adopt cross-sectional and fixed-effect (FE) estimation approaches.

Second is whether to focus on growth differences between war and non-warring nations, or alternatively to focus on the effects of war and non-war periods within given countries. The current empirical growth literature focuses on differences in growth between countries. Such cross-sectional analysis cannot discern whether conflict deters (or stimulates) growth, or instead whether low (or high) growth countries are simply more prone to conflict because of their innate country attributes. One way to better isolate the causal relationship is to examine whether growth changes within each country as conflict levels change. To do this one can employ a fixed-effect (FE) regression model. For this reason, we estimate a panel version of (2) where our units of observation are country-specific short-run growth rates (computed over five-year periods, two-year periods and computed annually).

Using a fixed effects regression is consistent with the neo-classical growth theory. FE models assume each country has its own growth rate determined not only by the exogenously given rates of savings, population growth, and technological progress, but also by country-specific factors that capture the differences in preferences and technology, and thus shape a unique growth path to the steady state. While the neo- 
classical growth framework implies an identical aggregate production function for all countries, introducing fixed effects allows for country-specific effects, where the aggregate production function can vary across countries.

Approximating around the steady state, the growth equation can be rewritten as:

$$
\begin{aligned}
& \operatorname{lng}_{\mathrm{tj}}=\left(1-\mathrm{e}^{-\lambda \tau}\right)[\alpha /(1-\alpha)] \ln (\mathrm{s})-\left(1-\mathrm{e}^{-\lambda \tau}\right)[\alpha /(1-\alpha)] \ln (\mathrm{n}+\mathrm{g}+\delta)+\mathrm{e}^{-\lambda \tau} \ln \mathrm{y}_{\mathrm{tj}-1} \\
& +\left(1-\mathrm{e}^{-\lambda \tau}\right) \ln \mathrm{A}_{0}+\mathrm{g}\left(\mathrm{t}_{\mathrm{j}}-\mathrm{e}^{-\lambda \tau} \mathrm{t}_{\mathrm{j}-1}\right)
\end{aligned}
$$

where $\lambda=(\mathrm{n}+\mathrm{g}+\delta)(1-\alpha)$ and $\tau=\left(\mathrm{t}_{\mathrm{j}}-\mathrm{t}_{\mathrm{j}-1}\right)$; and the time-invariant individual country effect term is $\left(1-\mathrm{e}^{-\lambda \tau}\right) \ln \mathrm{A}_{0}$. For consistency, the model uses the same variables as the previous single cross-sectional model, with two exceptions: the time-invariant variables, landlocked and tropics are dropped. ${ }^{22}$ In addition, recent empirical research on how religion affects the economy finds that Muslim population has a negative effect on economic growth. ${ }^{23}$ Because religion is also a time-invariant variable, it is not included in the fixed effects estimation. Finally, we address the question of how institutions and corruption influence growth by including the index of institutional quality, which the literature finds to have a strong positive association with economic growth. ${ }^{24}$ Therefore, the empirical version of this model is specified as

$$
\ln Y_{\text {it }}-\ln Y_{\text {it }-1}=\beta \ln Y_{o_{i t}}+\rho \mathbf{x}_{\text {it }}+\phi C_{i t}+\alpha_{i}+\theta_{t}+\varepsilon_{\text {it }}
$$

where the growth for country i during the one, two, or five-year period $t$ is considered. As in (3), $\ln \mathrm{Y}_{\mathrm{it}}$ is the value at the end of the period, $\ln \mathrm{Y}_{\mathrm{it}-1}$ is the value at the beginning of the period, and other independent variables are the averages taken over each period.

\footnotetext{
${ }^{22}$ A prominent literature on the effect of geography on growth emphasizes that a tropical location or a landlocked location have a negative influence on growth. Low-growth countries in Sub-Saharan Africa, for instance, have been heavily involved in both civil and international conflict. While these geography variables were highly important in a cross-sectional framework (primarily used in the early days of growth literature), our fixed effects estimation holds these variables constant.

${ }^{23}$ See, for example, McCleary and Barro (2006).

${ }^{24}$ The investment risk variable (described in Section IV of the paper) is computed as a rescaled average of the five sub-indices published by the PRS group (Political Risk Services). The index is also positively correlated with regime type, which therefore is omitted from our specification. We later stratify the sample by polity, which allows us to further examine whether democracies vs. non-democratic regimes are affected differently by conflict.
} 
Furthermore, $\beta=\mathrm{e}^{-\lambda \tau}$, and $\rho=\left(1-\mathrm{e}^{\lambda \tau}\right)[\alpha /(1-\alpha)]$ and $\mathrm{x}_{\mathrm{i}, \mathrm{t}}=\ln (\mathrm{s})-\ln (\mathrm{n}+\mathrm{g}+\delta) . \mathrm{C}_{\mathrm{it}}$ is the conflict variable, $\mathbf{x}_{\mathrm{it}}$ is a vector of control variables, and $\alpha_{\mathrm{i}}=\left(1-\mathrm{e}^{-\lambda \tau}\right) \ln \mathrm{A}_{0}$, and $\theta_{\mathrm{t}}=\mathrm{g}\left(\mathrm{t}_{2}\right.$ $\mathrm{e}^{-\lambda \tau_{1}} \mathrm{t}_{1}$ ) are country and period specific fixed effects, respectively. The parameter $\phi$ on the conflict variable is estimated as the average effect of conflict on growth. The parameter $\beta$ on lagged income per capita provides an estimate of the rate of convergence. It can also be interpreted to measure the initial stock of a country's capital. Due to data limitations, the openness variable is replaced by trade share representing the ratio of trade to GDP, the proportion of investment as a share of GDP, and government consumption as a proportion of GDP.

\section{The Results}

\section{A An Overview}

We first adopt the country-specific fixed effects model we just described; but to anchor our results to the previous section's cross-sectional estimation, we utilize a simple OLS for comparison purposes. The relevant coefficients from these regressions are in Table 4. The top panel consists of results for the five-year intervals; the middle panel contains estimates for the two-year time-intervals; and the bottom panel gives results for the one-year intervals. The first column contains fixed-effects estimates and the second OLS. Columns (3) and (4) follow the same pattern, but consist of regressions with twoyear moving averaged data which will be discussed later. Each column within the panel is divided in two: the top consists of regression coefficients comparable to column (2) of Table 3 containing coefficients for conflict duration, and the bottom consists of coefficients comparable to column (3) of Table 3 containing coefficients of conflict intensity. ${ }^{25}$ As in Table 3, the coefficients measure the percent change in growth associated with a unit change in conflict.

\footnotetext{
${ }^{25}$ Regression coefficients based on estimating the impact of each conflict variable separately (as opposed to grouping them by duration and intensity) yielded virtually identical results. As such, multicollinearity biases are not an issue because including all three conflict duration measures (or both conflict intensity measures) in one regression generated similar coefficient estimates as did estimating the impact of each conflict variable separately.
} 
The results are as follows: Both international and civil war coefficients are generally negative, and the coefficients for international wars are statistically significant. However, non-fatal conflict (defined as lower-level militarized interstate disputes, lower MIDs years) is associated with positive but statistically insignificant effects on growth, indicating that activities less hostile than war do not affect growth. More on this later. War intensity appears to measure the detrimental effects of war more precisely. Here all the coefficients tend to be negative and statistically significant. Thus severe wars are more deleterious to growth. By and large, all these results are comparable when examining yearly, two-year, or five-year time periods, however, the magnitudes are different.

\section{VII.B Magnitudes}

To interpret the magnitudes, recall the dependent variable is the annualized $\ln _{\mathrm{e}}$ difference in per capita income. Thus the estimated coefficient indicates the impact of a one unit change in the independent variable on the average annual growth rate. Therefore the -.4778 coefficient for war fatalities (upper MIDs fatality) indicates a $.5 \%$ lower per capita growth rate per unit increase in the number of war dead per thousand population. ${ }^{26}$ Similar interpretations apply to the civil war death variable, the civil war years variable, and the lower MIDs years variable. Of the war variables, the fatalities measures using five-year time periods are statistically significant, as is the war years in the one-year analysis.

\section{VII.C OLS Versus Fixed-Effects}

Regressions omitting the fixed-effects country specific parameter suffer from heterogeneity biases. Such biases mean estimated parameters potentially reflect country

\footnotetext{
${ }^{26}$ Conflict literature routinely measures fatality as the number of war deaths per capita multiplied by one thousand in order to calibrate the magnitudes of estimated coefficients.
} 
differences rather than the effects of conflict on growth. Because of this bias it is instructive to compare OLS and FE results. The more negative the OLS relative to the FE conflict coefficients the more likely low growth countries engage in conflict, and the less likely conflict decreases growth. Column (2) contains OLS results from equation (5) omitting the fixed effect parameter $\alpha_{i}$. Again, non-fatal conflict (lower-MIDS) duration has a positive though statistically insignificant effect on growth. International and civil war years are generally associated with lower growth, though these too tend to be statistically insignificant. On the other hand, fatalities from civil wars are strongly negative and statistically significant. The OLS regression based on shorter time intervals yields significantly more negative effects. It appears the negative coefficient of civil war fatalities is stronger than of international wars. Interestingly, the OLS coefficients do not greatly differ from FE. For international war years the coefficients are negative and statistically significant for one and two year time intervals. For civil war years they tend to be negative though not statistically significant. For MID duration they are positive but smaller in magnitude than the OLS coefficients, implying that higher growth countries more likely engage in low level conflict.

\section{VII.D Fatalities Versus Conflict Duration}

The other result is that fatalities appear to be negatively related to growth. For OLS, this result holds true for five-year, two-year and one-year time intervals, and is statistically significant for civil war fatalities. The FE civil war coefficients are negative and significant only for the five year intervals. In all instances the OLS coefficients are more negative than the FE coefficients indicating that low growth countries are more prone to civil wars. On the other hand, the FE upper MID fatality coefficients tend to be significantly negative and larger in magnitude than the comparable OLS coefficients. These latter coefficients indicate the deleterious growth effects of interstate war intensity, even when taking account of unmeasured heterogeneity.

\section{VII.E Controlling for Cyclic Effects}


One problem is that growth rates are erratic and often entail business cycles which are difficult to hold constant. For this reason, we recomputed columns (1) and (2) using two-year moving averages instead of annual growth rates. The results are qualitatively the same, but yield more precision (higher statistical significance) because the procedure accounts for noisy data. Columns (3) and (4) of Table 4 report the conflict coefficients for both techniques for one, two and five year time intervals. Again, severe wars (measured by battle fatalities) decrease growth. Lower level skirmishes appear to have no effect and war incidence has weak effects.

\section{VII.F Robustness Checks}

We also check the sensitivity of our results to changes in model specification. To do so, we re-specify the dependent variable to be income level expressed as a logarithm of real GDP per capita (as opposed to the change in the logarithm of per capita GDP). In addition to the previous explanatory variables, we include a trend variable, a conflict variable $^{27}$ and a trend-conflict interaction term. More formally, the specification is:

$$
\ln y_{i t}=\gamma_{0}+\gamma_{1} t+\gamma_{2} Z_{i t}+\gamma_{3} Z_{i t} \cdot t+\rho \chi_{i t}+\varepsilon_{i t}
$$

where $Z$ denotes the conflict variable and $t$ the time trend. The interaction term coefficient indicates the change in growth due to conflict. $\chi_{\text {it }}$ is the vector of control variables, which include trade, central government budget balance, institutional quality index, rate of population growth, life expectancy, investment, and government consumption. If the coefficient on the interaction variable is similar to the coefficient on the conflict variable in the original specification (where conflict duration and intensity measures are used), then both models are compatible, indicating similar implications regarding the effect of conflict on growth. The results are shown in Table 5. Here civil wars are related to a decrease in growth by $2 \%$ (OLS) and $0.6 \%$ (FE). As before the higher OLS coefficient implies less quickly growing countries are more prone to civil war. International wars are related to an annual decrease of .2 (OLS) to 1.2 (FE) percent in the level of GDP, while low-intensity conflict raises income from .13 (OLS) to .26

\footnotetext{
${ }^{27}$ We run five separate regressions, one for each conflict variable. The first three (civil war, international war and lower MID) are dichotomous variables which equal one if participating in a war and zero if not. The latter two measure war severity (the number of battle deaths in civil or international wars).
} 
(FE) annually. Here FE magnitudes exceed OLS estimates indicating a decline in growth even accounting for heterogeneity. Again, we find (especially for the FE estimation) that war casualties provide a strong measure of the negative effects of conflict on GDP level. Overall, we corroborate that both civil and international wars are associated with reduced growth, while low-intensity conflict may enhance it.

An important question about these results is robustness across countries. Do all countries exhibit the same effects of war? We answer this question in the next section.

\section{Sub-Sample Analysis}

To answer the above question regarding robustness across countries, we rerun equation (5) in three ways. First we break the countries up into five specific regions; second we examine countries based on polity; and third we separate counties by income level. Again we use both five-year and annual time intervals. As before, we find that sociopolitical conflict reduces growth, but the degree conflict lessens growth varies across country wealth, polity and conflict severity. ${ }^{28}$

\section{VIII.A Regional Differences}

The regional sub-samples we use are: 25 OECD countries, 22 Latin America, 29 Africa, and six Asian Tigers, each identified in Appendix A. Table 6 (Panel A) contains a summary of the analysis. We present coefficients for the three variables indicating the number of years at war (civil war years, international war years, and lower MIDs years) as well as for the civil and international war fatalities variables. We find civil wars negatively related to growth in most countries, and interstate wars especially detrimental to African country growth rates.

\footnotetext{
${ }^{28}$ As a robustness check, we also test a model specification where we interact years at war, and then war fatality variables with regional, income, and polity dichotomous variables (each dummy is also added separately, and the constant is suppressed in OLS estimation). Whether one- or five-year time intervals are analyzed, the results are quantitatively and qualitatively comparable.
} 
More specifically, in the OECD sample (column 1), only fatalities yield statistically significant results. Here a one-unit increase in civil war fatalities is associated with a decrease in growth by $60 \%$. To put this in perspective, this means that an OECD country experiences a $60 \%$ decline in growth if one-thousandth of its population dies in a civil war. It experiences a $164 \%$ decline if one-thousandth of its population dies in an international war.

For Latin America (column 2), no statistically significant effects were discernable. However, African countries exhibited large effects when wars are measured by fatalities (column 3 ). ${ }^{29}$ A civil war mortality of one-thousandth population decreases growth by over $4 \%$ and an international mortality rate of one-thousandth of population decreases growth by $284 \%$. The analysis of the Asian Tigers sample (column 4) shows negative (though statistically insignificant) growth rate effects for both civil war and international war fatalities. We found no statistically significant results for OPEC nations, except with regard to international wars, which in several model specifications appear to increase the rate of economic growth in oil exporting countries. One explanation of the positive effect of conflict on growth in the OPEC member nations might be OPEC oil producers suffer no gains from trade losses arising from conflict given the highly strategic nature of oil.

A possible explanation as to why there is so much variation in the impact of civil war fatalities on economic growth by country and by region might be that certain dyads experience multiple types of sociopolitical violence which arise due to complex causes and either overlap or closely follow in time, thereby reducing the prospect of economic recovery. This protracted and severe conflict would then have a particularly strong growth-reducing effect, as we have seen in the magnitudes of the estimated coefficients.

\footnotetext{
${ }^{29}$ These results are not driven by too few instances of war. Interstate wars in Africa include Uganda-Sudan, Chad-Sudan, Congo (former Zaire) and six other involved states, Ethiopia-Eritrea, and Tanzania-Uganda. And, according to Miguel, Satyanath, Sergenti (2003) "The major locus for civil wars in recent years has been Sub-Saharan Africa, where twenty seven of forty countries suffered from civil conflict during the 1980s and 1990s (PRIO 2002)."
} 
Below are some examples of such complex conflicts where countries were simultaneously involved in inter- and intra-state hostilities, respectively.

(1) Vietnam-Cambodia War 1975-1979 and Cambodia vs. Khmer Rouge 19701975.

(2) Bangladesh War 1971 and Pakistan vs. Bengalis 1971.

(3) Ethiopia-Somalia War 1977-1978 and Ethiopia vs. Somali Rebels 1976-1977, Ethiopia vs. Tigrean Liberation Front 1978-1991, Ethiopia vs. Eritrean Rebels 1974-1991.

(4) Uganda-Tanzania War 1978-1979 and Uganda vs. National Resistance Army 1980-1988.

(5) Iran-Iraq War 1980-1988 and Iran vs. Mujaheddin 1981-1982.

\section{VIII.B Differences by Income Groups}

Next, we posit that the effects of conflict vary from rich to poor economies. Using income level categories defined by the World Bank, we divide all the countries into three sub-samples based on income level. In line with the official classification, economies are divided into three groups according to 2005 GNI per capita: low income, $\$ 875$ or less; lower middle income, $\$ 876$ - $\$ 3,465$; upper middle income, $\$ 3,466$ - $\$ 10,725$; and high income, $\$ 10,726$ or more. ${ }^{30}$ For simplicity, the two middle income categories were combined into a single middle income category, thus yielding three sub-samples for this study, i.e. high income, middle income, and low income countries. Each group of countries was estimated individually. The results are contained in Table 6 (Panel B).

\footnotetext{
${ }^{30}$ http://web.worldbank.org/
} 
The analysis for the 25 high-income countries (column 1) reveal that deaths from international wars reduce the income growth rate (fatality measures are statistically significant for both the five-period and one-year analyses). No significant relationships were found in the middle-income grouping of 39 countries (column 2). Lastly, the examination of 16 low-income countries reveals the negative influences of fatalities from international war on economic growth (column 3). This result is consistent with that found in the African regional sample, and supports the contention that poor economies suffer the largest income growth reduction from the damage inflicted by war.

\section{VIII.C Differences by Political Regime}

It is also plausible that whether a given country is democratic or non-democratic determines how it would be affected by various forms of conflict. To explore this venue, the total sample was divided into two sub-samples using the democracy criterion.

For this purpose, we utilized the polity variable from Polity IV data. This measure assigns each country a democracy score ranging from ' -10 ' to ' 10 ', including a ' 0 '. Based on this variable, countries with a score of ' 6 ' or above were considered democratic, and those with a score below ' 6 ' were treated as non-democratic (Panel C).

In the sample of 56 democratic countries, there is a positive relationship between non-fatal conflict, or lower-level MIDs and economic growth rate. This finding reinforces the same result obtained for the OECD and high-income sub-samples, along with the hypothesis that containment of conflict at the lower level of hostility is conducive to economic growth.

Secondly, for democratic countries fatalities from international wars are associated with decreased growth - a finding not unlike that for high-income countries, and just as robust to changes in model specification. In 35 non-democratic countries, fatalities from civil wars are found to be negatively related to growth and statistically significant. 
The results for our regional analyses were also tested using the alternative specification described at the end of the previous section. The testing confirmed that Asian Tigers, African, and poor countries experience large negative effects of wars, while high-income countries and democracies, mostly face growth-reducing effects from international wars.

\section{Conclusion}

This study examines economic consequences of war within the empirical growth framework. To do so, we utilize panel data for 90 countries spanning 1970-2000. The data include real per capita GDP, country specific attributes, as well as five measures of domestic and international wars. From these we concentrate on how civil and international wars relate to country growth. We use short-term annual time-periods to get at the immediate effects of war, as well as time-periods spanning two, five and thirty years to get at long-term effects.

Our statistical analyses comprise both ordinary least squares and fixed-effects estimation techniques. The latter FE techniques hold constant country specific effects enabling us to measure the effects of wars within countries. The former amalgamate both cross-country and country-specific effects. Comparing results from both approaches enables us to make inferences about causality, namely whether more quickly growing countries are more likely to initiate conflict. Further, we stratify by our sample, reperforming the analysis by region, country wealth, and polity to examine whether the effects of war differ by country type.

Our main conclusions are: (1) The short-term effects of conflict are more pronounced than long-term effects. In short, countries recover from wars. (2) Poorer lowgrowth countries appear prone to civil wars, whereas richer high-growth countries to interstate wars. The effect of both is to decrease economic growth. Civil wars negatively affect all countries, and especially affect non-democracies. Interstate wars appear especially detrimental to African countries. (3) War severity measured by fatalities as a percent of a country's population appears to yield more robust measures of the effect of 
wars on country growth than war duration. Finally, (4) low-income countries suffer from wars more than high-income countries. 
Figure 1: Conflict and Per Capita GDP
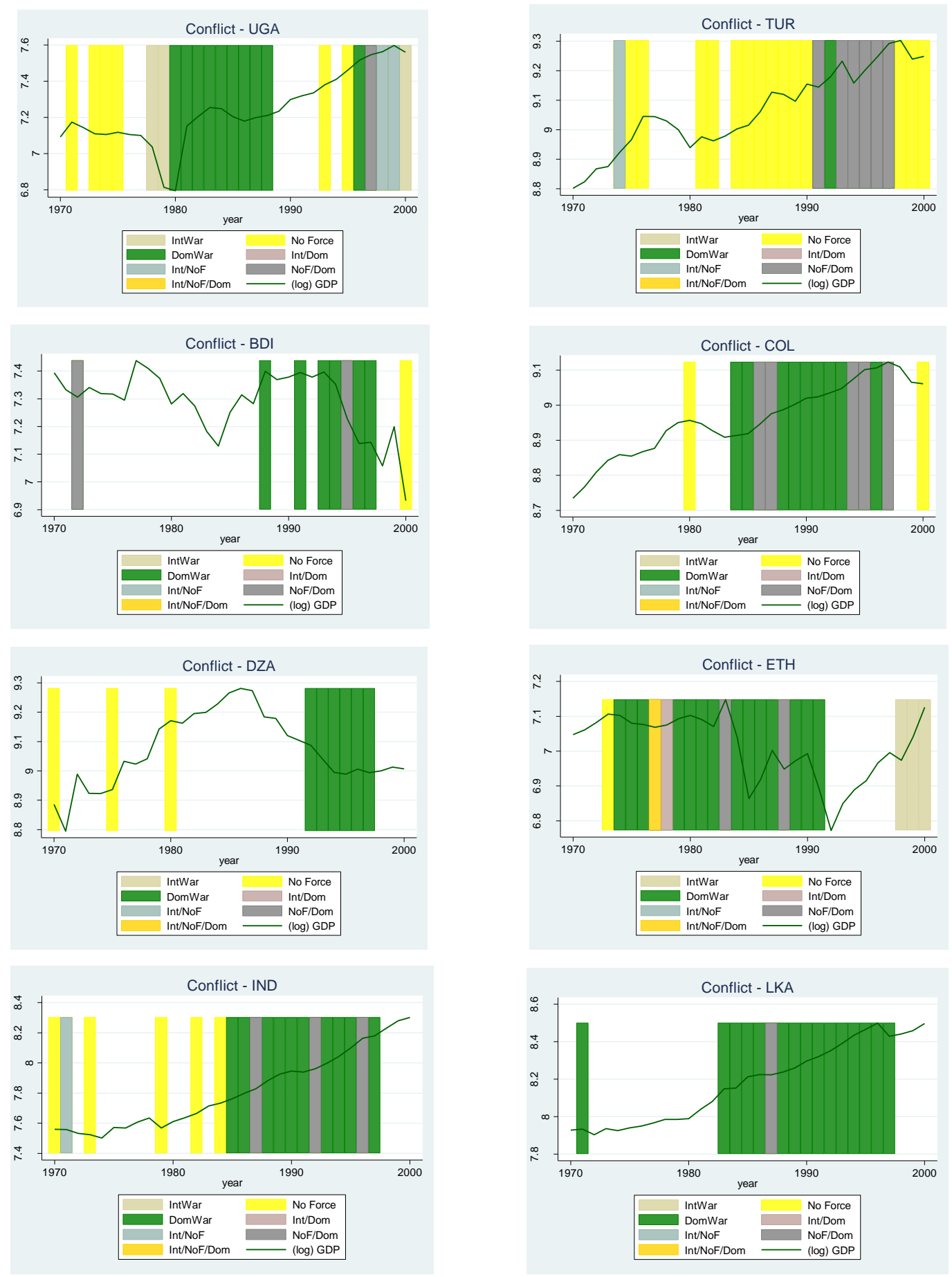

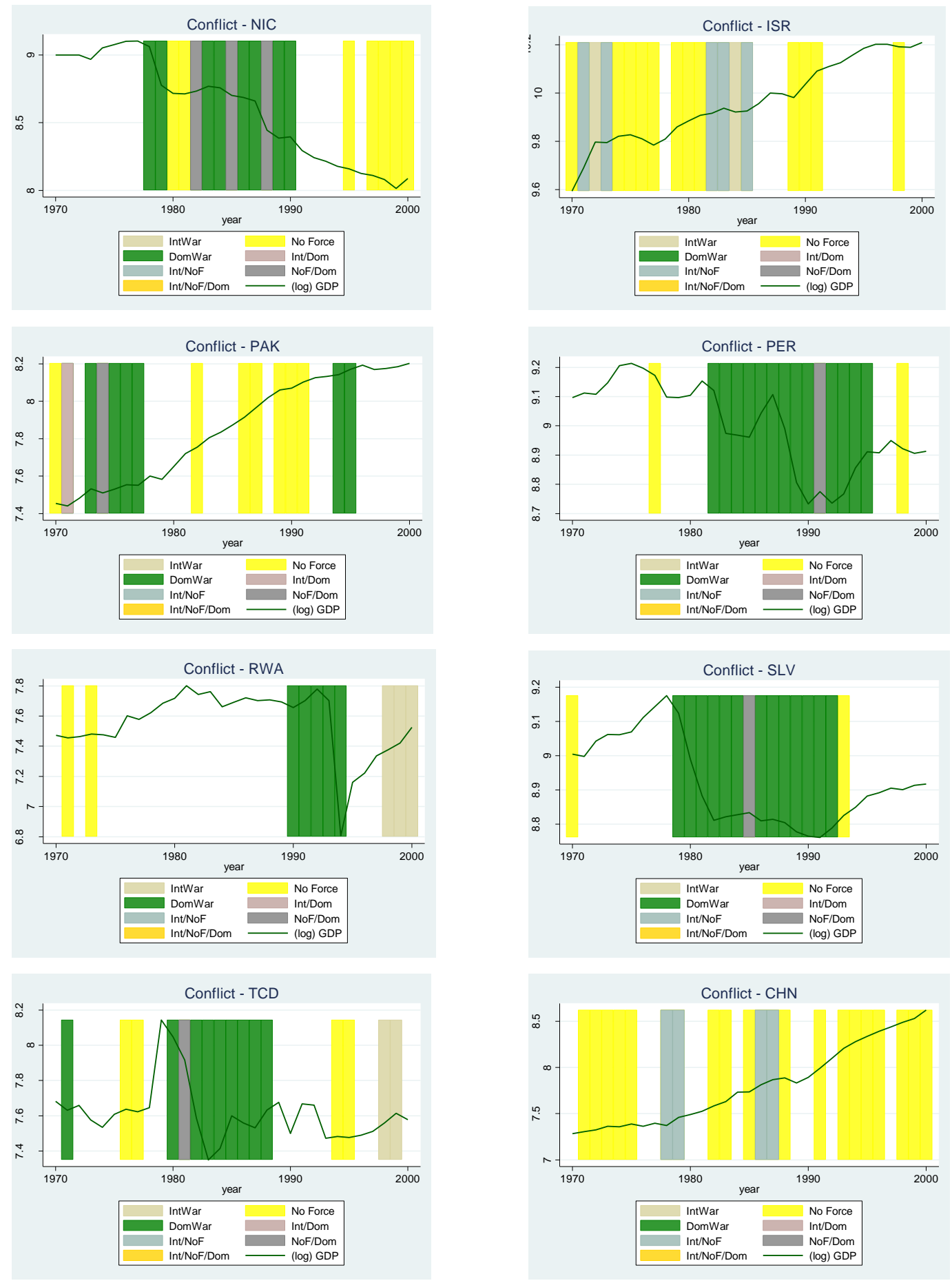
Table 1

Summary Statistics for All Variables

\begin{tabular}{|c|c|c|c|c|c|}
\hline Abbreviation & Definition $^{a}$ & Mean & Std. Dev. & Min & $\operatorname{Max}$ \\
\hline Grlngdp & $\begin{array}{l}\text { The average growth rate of real GDP } \\
\text { per economically active population in } \\
\text { 1970-2000 (PWT6.1). }\end{array}$ & 1.256861 & 2.012491 & -3.23467 & 7.246649 \\
\hline Laglngdp & $\begin{array}{l}\text { The log of real GDP per economically } \\
\text { active population in the base period } \\
\text { (PWT6.1). }\end{array}$ & 8.594688 & .9428799 & 6.619124 & 10.41 \\
\hline Open & $\begin{array}{l}\text { The trade openness index }[0,1] \text { as the } \\
\text { share of years a country was integrated } \\
\text { into the global economy in } 1970-2000 \\
\text { (based on Sachs and Warner } 1995 \text {, } \\
\text { 1997). }\end{array}$ & .3469019 & .4358744 & 0 & 1 \\
\hline Open*Laglngdp & $\begin{array}{l}\text { Interaction of "open" and "laglngdp", } \\
1970-2000 .\end{array}$ & 3.206776 & 4.137016 & 0 & 10.41 \\
\hline Tropics & $\begin{array}{l}\text { The share of country subjected to a } \\
\text { tropical climate }[0,1] \text { (Sachs and } \\
\text { Warner 1997). }\end{array}$ & .5677686 & .4701445 & 0 & 1 \\
\hline Access & $\begin{array}{l}\text { Landlocked country dummy, i.e. no } \\
\text { access to sea = (Sachs and Warner } \\
1995,1997) .\end{array}$ & .1885246 & .3927434 & 0 & 1 \\
\hline $\mathrm{Cgb}$ & $\begin{array}{l}\text { Central government budget balance, } \\
\text { computed as central government } \\
\text { revenues minus expenditures as a share } \\
\text { of GDP, i.e. average government } \\
\text { savings in 1970-2000 (WDI2004). }\end{array}$ & -3.169499 & 5.653045 & -23.51052 & 18.2243 \\
\hline Icrge $^{b}$ & $\begin{array}{l}\text { Institutional quality index (10- point } \\
\text { scale) in } 1970-2000 \text { published by the } \\
\text { PRS group (IRIS-3). }\end{array}$ & 5.653712 & 2.203877 & 2.185714 & 9.988571 \\
\hline Grpop & $\begin{array}{l}\text { Growth rate of economically active } \\
\text { population minus the growth rate of } \\
\text { total population in 1970-2000 } \\
\text { (WDI2004). }\end{array}$ & .2572844 & .4089627 & -.7131408 & 1.256329 \\
\hline Sxp & $\begin{array}{l}\text { Share of primary product exports (fuel } \\
\text { and non-fuel) in real GDP in the base } \\
\text { period (WDI2004). }\end{array}$ & .1198699 & .163954 & .0024843 & .89 \\
\hline Exlife & $\begin{array}{l}\text { Average life expectancy in the base } \\
\text { period (WDI2004). }\end{array}$ & 56.24249 & 11.72529 & 34.36341 & 74.64927 \\
\hline Exlifesqr & The square of "exlife". & 3299.554 & 1322.642 & 1180.844 & 5572.513 \\
\hline Polity2 & $\begin{array}{l}\text { Democracy measure from Polity IV } \\
\text { project, variable polity2. }\end{array}$ & .6910638 & 7.552719 & -10 & 10 \\
\hline Trade & $\begin{array}{l}\text { Share of imports and exports in real } \\
\text { GDP in 1970-2000 (WDI2004). }\end{array}$ & 68.92663 & 42.07816 & 7.979733 & 274.1847 \\
\hline
\end{tabular}

${ }^{a}$ The data sources are abbreviated as follows: Penn World Tables Mark6.1 - PWT6.1; World Development Indicators 2004, World Bank - WDI2004; IRIS-3 - International Risk Investment Survey, International Country Risk Guide (ICRG) Data by the Political Risk Services group; COW - Correlates of War, available online from Pennsylvania State University; MID - Militarized Interstate Dispute data compiled by the COW project.

${ }^{\mathrm{b}}$ See text for a more detailed description of the index. 


\section{Table 1, Continued}

\begin{tabular}{|c|c|c|c|c|c|}
\hline Investment & $\begin{array}{l}\text { Share of gross fixed capital formation in } \\
\text { real GDP in 1970-2000 (WDI2004). }\end{array}$ & 21.21366 & 6.841431 & 2.23354 & 58.57447 \\
\hline Ggc & $\begin{array}{l}\text { Share of the general government final } \\
\text { consumption expenditures in real GDP } \\
\text { in 1970-2000 (WDI2004). }\end{array}$ & 15.92191 & 6.623317 & 3.135428 & 56.40001 \\
\hline Sumdomwar ${ }^{\mathrm{c}}$ & $\begin{array}{l}\text { Number of years engaged in civil war in } \\
1970-2000 \text { (COW v3.0) years. }\end{array}$ & .0858704 & .1936608 & 0 & .9047619 \\
\hline Summidnofatal & $\begin{array}{l}\text { Aggregated interstate events data on: } \\
\text { lower MIDs 1-3, no militarized action, } \\
\text { threat to use, and display of force; } \\
\text { number of years engaged in low-level } \\
\text { MIDs in 1970-2000 (MID v3.02 data). }\end{array}$ & .1807182 & .1827372 & 0 & .9047619 \\
\hline Summidfatal & $\begin{array}{l}\text { Aggregated interstate events data on: } \\
\text { upper MIDs 4-5, use of force and war; } \\
\text { number of years engaged in upper-level } \\
\text { MIDs in 1970-2000 (MID v3.02 data). }\end{array}$ & .204918 & .2419514 & 0 & .9047619 \\
\hline Summidwar $^{\mathrm{d}}$ & $\begin{array}{l}\text { Number of years engaged in } \\
\text { international war in 1970-2000 (MID } \\
\text { v3.02 data). }\end{array}$ & .0249805 & .0770059 & 0 & .5238096 \\
\hline Civfatality & $\begin{array}{l}\text { Number of deaths from civil war per } \\
\text { thousand of population in 1970-2000 } \\
\text { (COW v3.0). }\end{array}$ & .6805628 & 4.081746 & 0 & 70.13132 \\
\hline Midfatality & $\begin{array}{l}\text { Number of deaths from fatal forms of } \\
\text { conflict per thousand of population, i.e. } \\
\text { upper MIDs (use of force and war) in } \\
\text { 1970-2000 (MID v3.02). }\end{array}$ & .1019104 & .9885795 & 0 & 14.63357 \\
\hline
\end{tabular}

\footnotetext{
${ }^{\mathrm{c}}$ Each war and conflict variable is coded as a dummy in models based on annual data.

${ }^{\mathrm{d}}$ The correlation coefficient (significant at the .05 level) between interstate war index computed with COW data and the index computed with MIDs data is 0.9122 , i.e. the two datasets do not exactly map into each other. The data used are from COW V3.0, Inter-state War Participants (data on state participation in interstat wars) and midB V3.02 (data on MIDs from 1816-2001, at the participant level; contains one record per militarized dispute participant.)
} 
Table 2

Conflict Variables: Correlation Coefficients ${ }^{31}$

\begin{tabular}{|c|c|c|c|}
\hline & & $\begin{array}{c}\text { Five-Year Time } \\
\text { Intervals }\end{array}$ & \\
\hline Civil War Years & 1 & & \\
\hline International War Years & 0.0322 & 1 & \\
\hline \multirow[t]{2}{*}{ Lower MIDs Years } & -0.2727 & 0.114 & 1 \\
\hline & & $\begin{array}{l}\text { Two-Year Time } \\
\text { Intervals }\end{array}$ & \\
\hline Civil War Years & 1 & & \\
\hline International War Years & -0.064 & 1 & \\
\hline \multirow[t]{2}{*}{ Lower MIDs Years } & -0.5885 & -0.2399 & 1 \\
\hline & & $\begin{array}{c}\text { One-Year Time } \\
\text { Intervals }\end{array}$ & \\
\hline Civil War Years & 1 & & \\
\hline International War Years & -0.0728 & 1 & \\
\hline Lower MIDs Years & -0.9236 & -0.2082 & 1 \\
\hline
\end{tabular}

\footnotetext{
${ }^{31}$ Missing observations for these variables were deleted for the purpose of estimating the correlation coefficients.
} 
Table 3

Single Cross-Section OLS Results, 1970-2000

\begin{tabular}{|c|c|c|c|c|}
\hline \multirow[t]{2}{*}{ Independent Variables } & \multirow[b]{2}{*}{ Sachs-Warner } & \multicolumn{2}{|r|}{ Variations $*$} & \multirow[b]{2}{*}{ (3) } \\
\hline & & (1) & (2) & \\
\hline lagged income & -1.5084 & -1.2660 & -1.2625 & -1.2747 \\
\hline (Laglngdp) & $(0.2305)$ & $(0.2553)$ & $(.2512)$ & $(.2582)$ \\
\hline openness index & 10.7347 & 9.9590 & 9.3253 & 9.8867 \\
\hline (Open) & $(2.9312)$ & $(4.3502)$ & $(4.5060)$ & $(4.4173)$ \\
\hline openness index*lagged income & -1.0512 & -.9906 & -.9022 & -.9840 \\
\hline$($ Open*Laglngdp) & $(0.3577)$ & $(0.5113)$ & $(.5322)$ & $(.5194)$ \\
\hline Tropics & -0.8532 & -1.3244 & -1.1865 & -1.3853 \\
\hline (Tropics) & $(0.2787)$ & $(0.3354)$ & $(.3653)$ & $(.3638)$ \\
\hline landlocked & -0.5904 & -.0702 & -.1144 & -.0862 \\
\hline (Access) & $(0.2504)$ & $(0.3447)$ & $(.3575)$ & $(.3511)$ \\
\hline government budget balance & .1165 & & & \\
\hline$(\mathrm{Cgb})$ & $(.0220)$ & & & \\
\hline institutional quality index & .3070 & .4025 & .3807 & .3918 \\
\hline (Icrge) & $(.0819)$ & $(.1408)$ & $(.1466)$ & $(.1442)$ \\
\hline population growth & .7716 & .0320 & .0645 & -.0186 \\
\hline (Grpop) & $(.3648)$ & $(.5271)$ & $(.5404)$ & $(.5491)$ \\
\hline primary product exports & -3.9538 & & & \\
\hline$(\mathrm{Sxp})$ & $(.9850)$ & & & \\
\hline life expectancy & .3338 & .1944 & .2091 & .2104 \\
\hline (Exlife) & $(.1224)$ & $(.1715)$ & $(.1820)$ & $(.1771)$ \\
\hline life expectancy squared & -.0025 & -.0012 & -.0014 & -.0014 \\
\hline (Exlifesqr) & $(.0011)$ & $(0.0016)$ & $(.0017)$ & $(.0016)$ \\
\hline civil war & & & -.4975 & \\
\hline (Sumdomwar) & & & (.6918) & \\
\hline international war & & & 2.0926 & \\
\hline (Summidwar) & & & $(2.4625)$ & \\
\hline lower MIDs & & & -.0166 & \\
\hline (Summidnofatal) & & & $(.7419)$ & \\
\hline civil war fatality & & & & $-9.21 \mathrm{e}-07$ \\
\hline (Civfatality) & & & & $(1.95 \mathrm{e}-06)$ \\
\hline upper MIDs fatality & & & & $-3.05 e-07$ \\
\hline (Midfatality) & & & & $(1.43 e-06)$ \\
\hline Constant & 2.0584 & 2.9919 & 2.6058 & 2.7834 \\
\hline & $(3.3211)$ & $(4.9272)$ & $(5.0711)$ & $(5.0055)$ \\
\hline R-squared & 0.8666 & 0.6223 & .6294 & .6237 \\
\hline
\end{tabular}

Dependent variable is average growth rate of real GDP per worker in 1970-2000

(log difference in real GDP per working age person divided by the number of years)

White's robust standard errors are in parentheses. Number of observations $=81$.

Bold coefficients indicate statistical significance at the 5\% level. 
Table 4

The Percent Impact of Conflict on Growth Between (OLS) and Within (Fixed-Effects) Countries

\begin{tabular}{|c|c|c|c|c|}
\hline \multirow[b]{2}{*}{ Conflict Variables } & \multicolumn{4}{|c|}{ Five-Year Time Intervals } \\
\hline & Fixed-Effects & OLS & Fixed-Effects & OLS \\
\hline Civil War Years & $\begin{array}{c}-.0118 \\
(0.1150)\end{array}$ & $\begin{array}{l}-0.1076 \\
(0.0898)\end{array}$ & $\begin{array}{l}-0.1008 \\
(0.5298)\end{array}$ & $\begin{array}{l}-0.4689 \\
(0.3979)\end{array}$ \\
\hline \multicolumn{5}{|l|}{ International War } \\
\hline Years & $\begin{array}{l}-0.1782 \\
(.2175)\end{array}$ & $\begin{array}{c}.3024 \\
(.2027)\end{array}$ & $\begin{array}{l}-0.5493 \\
(1.0270)\end{array}$ & $\begin{array}{c}0.9907 \\
(0.9479)\end{array}$ \\
\hline Lower MIDs Years & $\begin{array}{c}0.1551 \\
(0.1095)\end{array}$ & $\begin{array}{c}0.1414 \\
(0.0851)\end{array}$ & $\begin{array}{c}0.6483 \\
(0.5380)\end{array}$ & $\begin{array}{c}0.4800 \\
(0.4090)\end{array}$ \\
\hline Civil War Fatalities & $\begin{array}{c}-.2145 \\
(0.1252)\end{array}$ & $\begin{array}{c}-.2568 \\
(0.1062)\end{array}$ & $\begin{array}{l}\mathbf{- 0 . 2 6 9 8} \\
(0.1220)\end{array}$ & $\begin{array}{l}\mathbf{- 0 . 2 5 1 5} \\
(0.1028)\end{array}$ \\
\hline \multirow[t]{3}{*}{ Upper MIDs Fatalities } & $\begin{array}{l}-.4778 \\
(.2549)\end{array}$ & $\begin{array}{l}-0.1816 \\
(.2043)\end{array}$ & $\begin{array}{l}-0.3941 \\
(0.2520)\end{array}$ & $\begin{array}{l}-0.1333 \\
(0.1986)\end{array}$ \\
\hline & & o-Year Tin & atervals & \\
\hline & Fixed-Effects & OLS & Fixed-Effects & OLS \\
\hline Civil War Years & $\begin{array}{l}0.0178 \\
(.1859)\end{array}$ & $\begin{array}{l}-0.2458 \\
(0.1408)\end{array}$ & $\begin{array}{l}-0.0450 \\
(0.1494)\end{array}$ & $\begin{array}{l}-0.1318 \\
(0.1133)\end{array}$ \\
\hline \multicolumn{5}{|l|}{ International War } \\
\hline Years & $\begin{array}{l}-0.6683 \\
(.3424)\end{array}$ & $\begin{array}{l}-0.1060 \\
(0.3180)\end{array}$ & $\begin{array}{l}-0.4992 \\
(0.2725)\end{array}$ & $\begin{array}{l}-0.1289 \\
(0.2540)\end{array}$ \\
\hline Lower MIDs Years & $\begin{array}{l}0.0610 \\
(.1236)\end{array}$ & $\begin{array}{c}0.2019 \\
(0.1088)\end{array}$ & $\begin{array}{c}.1260 \\
(0.0992)\end{array}$ & $\begin{array}{c}\mathbf{0 . 1 8 3 1} \\
(0.0875)\end{array}$ \\
\hline Civil War Fatalities & $\begin{array}{c}0.3284 \\
(0.5633)\end{array}$ & $\begin{array}{l}-0.6607 \\
(0.3496)\end{array}$ & $\begin{array}{l}-0.0497 \\
(0.4553)\end{array}$ & $\begin{array}{l}\mathbf{- 0 . 7 1 3 1} \\
(0.2806)\end{array}$ \\
\hline \multirow[t]{3}{*}{ Upper MIDs Fatalities } & $\begin{array}{l}\mathbf{- 2 . 5 7 8 3} \\
(1.0607) \\
\end{array}$ & $\begin{array}{l}-0.4233 \\
(0.7092)\end{array}$ & $\begin{array}{c}-\mathbf{2 . 2 0 1 0} \\
(0.8529) \\
\end{array}$ & $\begin{array}{l}-1.0595 \\
(0.5689) \\
\end{array}$ \\
\hline & & e-Year Tin & tervals & \\
\hline & Fixed-Effects & OLS & Fixed-Effects & OLS \\
\hline Civil War Years & $\begin{array}{l}-0.1286 \\
(0.7211)\end{array}$ & $\begin{array}{l}-0.7921 \\
(0.4940)\end{array}$ & $\begin{array}{l}-0.2446 \\
(0.4295)\end{array}$ & $\begin{array}{l}-0.4931 \\
(0.3226)\end{array}$ \\
\hline \multicolumn{5}{|l|}{ International War } \\
\hline Years & $\begin{array}{l}\mathbf{- 2 . 7 7 3 5} \\
(1.2442)\end{array}$ & $\begin{array}{l}-2.0070 \\
(1.1328)\end{array}$ & $\begin{array}{l}\mathbf{- 1 . 4 4 3 8} \\
(0.7146)\end{array}$ & $\begin{array}{l}-0.6605 \\
(0.6967)\end{array}$ \\
\hline Lower MIDs Years & $\begin{array}{c}0.3256 \\
(0.3619)\end{array}$ & $\begin{array}{c}\mathbf{0 . 7 2 4 6} \\
(0.3351)\end{array}$ & $\begin{array}{l}-0.0610 \\
(0.2365)\end{array}$ & $\begin{array}{c}0.3161 \\
(0.2242)\end{array}$ \\
\hline Civil War Fatalities & $\begin{array}{c}0.4867 \\
(0.8168)\end{array}$ & $\begin{array}{l}\mathbf{- 1 . 2 3 0 3} \\
(0.5685)\end{array}$ & $\begin{array}{c}0.1664 \\
(0.6118)\end{array}$ & $\begin{array}{l}\mathbf{- 1 . 1 0 0 8} \\
(0.4336)\end{array}$ \\
\hline Upper MIDs Fatalities & $\begin{array}{l}-1.3527 \\
(1.5043)\end{array}$ & $\begin{array}{l}-0.9761 \\
(1.0347)\end{array}$ & $\begin{array}{l}\mathbf{- 2 . 2 5 0 6} \\
(1.1209)\end{array}$ & $\begin{array}{l}-1.4936 \\
(0.7888)\end{array}$ \\
\hline
\end{tabular}

Coefficients of growth regressions where dependent variables is the average growth rate of real GDP per worker over each specified time-period (log difference in real GDP per working age person divided by the number of year in the time period) and the independent variables are the indicated conflict measures. The left two columns repeat results reported in Tables 3 and 4. The right two columns use two-year moving average data for growth. Standard errors in parentheses. 
Table 5

The Percent Impact of Conflict on Annual Growth: The Original and An Alternative Specification

\begin{tabular}{|c|c|c|c|c|}
\hline Conflict Variables & $\begin{array}{l}\text { Original } \\
\text { OLS }^{\mathrm{a}}\end{array}$ & $\begin{array}{l}\text { Alternative } \\
\text { OLS }\end{array}$ & $\begin{array}{l}\text { Original } \\
\mathrm{FE}^{\mathrm{a}}\end{array}$ & $\begin{array}{l}\text { Alternative } \\
\text { FE }^{\mathrm{b}}\end{array}$ \\
\hline Civil War Years & $\begin{array}{l}-0.0079 \\
(0.0049)\end{array}$ & $\begin{array}{c}\text { conflict*trend } \\
\mathbf{- 0 . 0 2 0 8} \\
(0.0055)\end{array}$ & $\begin{array}{l}-0.0013 \\
(0.0072)\end{array}$ & $\begin{array}{c}\text { conflict*trend } \\
\mathbf{- 0 . 0 0 6 5} \\
(0.0021)\end{array}$ \\
\hline International War Years & $\begin{array}{l}-0.0201 \\
(0.0113)\end{array}$ & $\begin{array}{c}\mathbf{- 0 . 0 0 2 0} \\
(0.0099)\end{array}$ & $\begin{array}{l}\mathbf{- 0 . 0 2 7 7} \\
(0.0124)\end{array}$ & $\begin{array}{c}-\mathbf{- 0 . 0 1 1 2} \\
(0.0038)\end{array}$ \\
\hline Lower MIDs Years & $\begin{array}{c}\mathbf{0 . 0 0 7 2} \\
(0.0034)\end{array}$ & $\begin{array}{c}0.0013 \\
(0.0030)\end{array}$ & $\begin{array}{c}0.0033 \\
(0.0036)\end{array}$ & $\begin{array}{c}\mathbf{0 . 0 0 2 6} \\
(0.0011)\end{array}$ \\
\hline Civil War Fatalities & $\begin{array}{l}\mathbf{- 0 . 0 1 2 3} \\
(0.0057)\end{array}$ & $\begin{array}{c}-.0142 \\
(0.0043)\end{array}$ & $\begin{array}{c}0.0049 \\
(0.0082)\end{array}$ & $\begin{array}{l}-0.0122 \\
(0.0018)\end{array}$ \\
\hline Upper MIDs Fatalities & $\begin{array}{l}-0.0098 \\
(0.0103)\end{array}$ & $\begin{array}{c}.0011 \\
(0.0209)\end{array}$ & $\begin{array}{l}-0.0135 \\
(0.0150)\end{array}$ & $\begin{array}{l}-0.0140 \\
(0.0075) \\
\end{array}$ \\
\hline
\end{tabular}

${ }^{a}$ Coefficients of the fatality variable on growth rates computed as: $(\ln Y(t)-\ln Y(t-1)) *(100)$; Number of Observations: 2023; Number of Countries: 90

${ }^{\mathrm{b}}$ Coefficients of the conflict variable in level of per capita GDP Number of Observations: 3390; Number of Countries: 90.

Standard errors in parentheses. Bold coefficients indicate statistical significance at the $5 \%$ level. 
Table 6

The Percent Impact of conflict on Growth

Fixed Effects Results, 1970-2000 by Country Type

(A) The Impact of Conflict on Growth by Type of Country Based on Region

Five-Year time Intervals

\begin{tabular}{|l|c|c|c|c|c|}
\hline \multirow{4}{*}{ Conflict Variables } & & & & \\
\hline Civil War Years & OECD & Latin America & Africa & Asian Tigers & OPEC \\
& -0.3215 & -0.1065 & -0.6000 & -6.3720 & -4.0970 \\
International War Years & $(1.4585)$ & $(1.3125)$ & $(1.0475)$ & $(3.4510)$ & $(2.8910)$ \\
& 2.2440 & & -3.8870 & & $\mathbf{7 . 5 4 4 5}$ \\
& $(2.2990)$ & & $(1.9870)$ & & $(2.3225)$ \\
& 0.6830 & -0.1090 & -0.6895 & 1.2970 & -2.7680 \\
& $(0.6215)$ & $(1.6120)$ & $(1.0570)$ & $(1.5985)$ & $(2.1430)$ \\
Lower MIDs Years & & & & & \\
\cline { 2 - 6 } Upivil War Fatalities & -17.5750 & -0.3025 & -2.6745 & -516.1620 & -12.9435 \\
& $(26.7300)$ & $(1.0385)$ & $(1.7765)$ & $(283.1155)$ & $(11.3590)$ \\
& 3.6600 & -91.7735 & $\mathbf{- 1 8 6 . 6 2 0 5}$ & -383.7675 & -0.5290 \\
& $(54.3205)$ & $(124.4770)$ & $(49.4200)$ & $(1363.3195)$ & $(2.7675)$ \\
\hline
\end{tabular}

Growth rates computed as: $(\ln Y(t)-\ln Y(t-5)) *(100 / 5)$; adjusting for lagged income, trade share, government budget balance, institutional quality index, population growth, life expectancy, investment share, and government consumption share. Standard errors in parentheses.

One-Year Time Intervals

\begin{tabular}{|l|c|c|c|c|c|}
\hline Conflict Variables & OECD & Latin America & Africa & Asian Tigers & OPEC \\
\hline Civil War Years & -1.0256 & -0.8871 & 0.0597 & & 1.9587 \\
& $(2.1741)$ & $(1.2960)$ & $(1.6492)$ & & $(2.6717)$ \\
International War Years & -2.1049 & & $\mathbf{- 9 . 5 6 4 2}$ & & 2.0282 \\
& $(1.1585)$ & & $(3.5987)$ & & $(3.9043)$ \\
& 0.1694 & -0.3083 & -0.6364 & 0.0099 & 2.7167 \\
& $(0.3481)$ & $(0.8365)$ & $(0.8681)$ & $(0.5900)$ & $(1.9857)$ \\
& & & & & \\
Civil War Fatalities & & & & & \\
\cline { 2 - 7 } & $\mathbf{- 6 0 . 2 6 6 6}$ & 1.9495 & -4.0767 & -593.7900 & 60.4447 \\
& $(27.4388)$ & $(1.1982)$ & $(2.5492)$ & $(424.3470)$ & $(46.3470)$ \\
& -164.2300 & -0.9357 & $\mathbf{- 2 8 4 . 1 2 2 4}$ & -962.6589 & 4.9457 \\
& $(109.2633)$ & $(116.0157)$ & $(83.5672)$ & $(1464.6840)$ & $(3.0316)$ \\
\hline
\end{tabular}

Growth rates computed as: $(\ln Y(t)-\ln Y(t-1)) *(100)$; adjusting for lagged income, trade share, government budget balance, institutional quality index, population growth, life expectancy, investment share, and government consumption share. Standard errors in parentheses. 
(B) The Impact of Conflict on Growth by Type of Country Based on Income Five-Year time Intervals

\begin{tabular}{|l|c|c|c|}
\hline Conflict Variables & High-Income & Middle-Income & Low-Income \\
\hline Civil War Years & & -0.1420 & 0.3055 \\
& & $(0.8390)$ & $(1.3590)$ \\
International War Years & -1.028 & & \\
& $(1.4605)$ & 0.3295 & -5.6685 \\
Lower MIDs Years & 1.1755 & $(1.8070)$ & $(3.5240)$ \\
& $(0.7350)$ & -0.0165 & -0.1300 \\
Civil War Fatalities & & $(0.9205)$ & $(1.3175)$ \\
\cline { 2 - 4 } & & -0.1210 & -0.3875 \\
Upper MIDs Fatalities & & $(0.8525)$ & $(1.2410)$ \\
& & -2.0675 & $\mathbf{- 2 2 0 . 0 2 4 0}$ \\
& $\mathbf{- 2 2 . 4 2 2 5}$ & $(1.4465)$ & $(76.9985)$ \\
\hline
\end{tabular}

Growth rates computed as: $(\ln Y(t)-\ln Y(t-5))^{*}(100 / 5)$; adjusting for lagged income, trade share, government budget balance, institutional quality index, population growth, life expectancy, investment share, and government consumption share. Standard errors in parentheses.

One-Year Time Intervals

\begin{tabular}{|l|c|c|c|}
\hline Conflict Variables & High-Income & Middle-Income & Low-Income \\
\hline Civil War Years & & -0.0546 & -0.3758 \\
& & $(1.1004)$ & $(1.2557)$ \\
International War Years & -1.9325 & -0.3804 & $\mathbf{- 1 8 . 0 2 6 4}$ \\
& $(1.1006)$ & $(2.0616)$ & $(4.1693)$ \\
& 0.1515 & 0.6736 & -0.8033 \\
& $(0.3679)$ & $(0.6068)$ & $(0.8678)$ \\
Cower MIDs Years & & & \\
& & & -1.2089 \\
Upper MIDs Fatalities & & $\mathbf{2 . 2 2 5 4}$ & $(2.1999)$ \\
& & $(1.0412)$ & $\mathbf{- 3 1 1 . 6 6 5 9}$ \\
& $\mathbf{- 5 8 . 3 8 6 2}$ & -1.7831 & $(100.9576)$ \\
\hline
\end{tabular}

Growth rates computed as: $(\ln Y(t)-\ln Y(t-1))^{*}(100)$; adjusting for lagged income, trade share, government budget balance, institutional quality index, population growth, life expectancy, investment share, and government consumption share. Standard errors in parentheses. Bold coefficients indicate statistical significance at the $5 \%$ level. 
(C) The Impact of Conflict on Growth by Type of Polity

\begin{tabular}{|l|c|c|}
\hline Conflict Variables & Democratic & Non-Democratic \\
\hline Civil War Years & 0.6300 & -0.7910 \\
& $(0.7710)$ & $(0.9315)$ \\
International War Years & -2.0820 & -0.3185 \\
& $(1.8565)$ & $(1.4920)$ \\
Lower MIDs Years & 1.0900 & -0.3765 \\
& $(0.6530)$ & $(1.0115)$ \\
Civil War Fatalities & & \\
Upper MIDs Fatalities & -0.8295 & -2.2275 \\
& $(0.7080)$ & $(1.2230)$ \\
& $\mathbf{- 2 2 . 8 3 7 0}$ & -2.3945 \\
\hline
\end{tabular}

Five-Year time Intervals

Growth rates computed as: $(\ln Y(t)-\ln Y(t-5)) *(100 / 5)$; adjusting for lagged income, trade share, government budget balance, institutional quality index, population growth, life expectancy, investment share, and government consumption share. Standard errors in parentheses.

One-Year Time Intervals

\begin{tabular}{|l|c|c|}
\hline Conflict Variables & Democratic & Non-Democratic \\
\hline Civil War Years & -0.1145 & -0.3595 \\
& $(0.9089)$ & $(1.2522)$ \\
International War Years & -1.7793 & $\mathbf{- 4 . 3 7 3 4}$ \\
& $(1.5006)$ & $(2.1627)$ \\
Lower MIDs Years & 0.0033 & 1.0099 \\
& $(0.3509)$ & $(0.8061)$ \\
Civil War Fatalities & & \\
& & -4.0006 \\
Upper MIDs Fatalities & 0.8751 & $(2.1276)$ \\
& $(0.7713)$ & -0.9426 \\
& $\mathbf{- 6 0 . 1 7 9 5}$ & $(2.0286)$ \\
\hline
\end{tabular}

Growth rates computed as: $(\ln Y(t)-\ln Y(t-1))^{*}(100)$; adjusting for lagged income, trade share, government budget balance, institutional quality index, population growth, life expectancy, investment share, and government consumption share. Standard errors in parentheses. 


\section{References}

Aizenman, Joshua, and Nancy Marion. 1993. "Macroeconomic Uncertainty and Private Investment." Economic Letters 41: 207-210.

Alesina, A., Easterly, W., and Matuszeski, J. 2006. “Artificial States.” NBER Working Paper No. 12328.

Alesina, A., Devleeschauwer, A., Easterly, W., Kurlat, S., Wacziarg, R. 2003.

"Fractionalization." Journal of Economic Growth 8(2): 155-194.

Alesina, Alberto F., Sule Oezler, Nouriel Roubini, and Philip Swagel. 1996. "Political

Instability and Economic Growth.” Journal of Economic Growth 1: 189-211.

Alesina, Alberto F., and Roberto Perotti. 1996. "Income Distribution, Political Instability and Investment." European Economic Review 80: 1203-1228.

Alesina, Alberto F., and Guido Tabellini. 1989. "External Debt, Capital Flight and Political Risk.” Journal of International Economics 27:199-220.

Barro, Robert J. 1991. "Economic Growth in a Cross Section of Countries, “Quarterly Journal of Economics 106(2): 407-444.

Barro, Robert J. 1997. Determinants of Economic Growth: A Cross-Country Empirical Study. Lionel Robbins Lectures. Cambridge, Mass.: MIT Press.

Barro, Robert J., and Jong-Wha Lee. 1993. "Losers and Winners in Economic Growth." NBER Working Paper No. 4341.

Barro, Robert J., and Xavier Sala-i-Martin. 1992. "Convergence.” The Journal of Political Economy 100(2): 223-251. 
Barro, Robert J., and Xavier Sala-i-Martin. 1995. "Economic Growth.” New York: McGraw-Hill.

Barro, Robert J., and Holger Wolf. 1989. "Data Appendix for Economic Growth in a Cross Section of Countries." Mimeo Cambridge MA.: Harvard University.

Baumol, William J. 1986. "Productivity Growth, Convergence, and Welfare: What The Long-Run Data Show?” American Economic Review LXXVI (1986): 1072-1085.

Beck, Nathaniel, and Jonathan N. Katz. 1995. "What to Do (and Not to Do) with TimeSeries Cross-Section Data.” The American Political Science Review 89(3): 634-647.

Blomberg, S. Brock, and Gregory D. Hess. 2002. "The Temporal Links between Conflict and Economic Activity." The Journal of Conflict Resolution 46(1): 74-90.

Borooah, V.K., and Paldam, M. 2007. "Why is the world short of democracy?: Acrosscountry analysis of barriers to representative government." European Journal of Political Economy 23: 582-604.

Brock, W., and Durlauf, S. 2002. "Market Implications of Peer and Neighborhood Effects: A Multinomial Choice Model of Neighborhood Effects." American Economic Review 92(2): 298-303.

Brunetti, Aymo. 1997. "Political Variables in Cross-Country Growth Analysis," Journal of Economic Surveys 11: 163-190.

Burnside, Craig, and David Dollar. 2000. "Aid, Policies, and Growth.” American Economic Review 90(4): 847-868.

Butkiewicz, James L., and Halit Yanikkaya. 2005. “The Impact of Sociopolitical Instability on Economic Growth: Analysis and Implications," Journal of Policy Modeling, 27: 629-645. 
Chauvet, Lisa. 2003. "Socio-political instability and the allocation of international aid by donors," European Journal of Political Economy, Elsevier, 19(1): 33-59.

Collier, Paul. 2007. The Bottom Billion: Why the Poorest Countries Are Failing and What Can Be Done About It. Oxford University Press.

Collier, Paul, Lance Elliot, Håvard Hegre, Anke Hoeffler, Marta Reynal-Querol, and Nicholas Sambanis. 2003. Breaking the Conflict Trap: Civil War and Development Policy. Oxford and Washington DC: Oxford University Press and World Bank.

Collier, Paul, and Nicholas Sambanis. 2002. "Understanding Civil War: A New Agenda." Journal of Conflict Resolution 46(1): 3-12.

Diehl, Paul F. 1983. "Arms Races and Escalation: A Closer Look." Journal of Peace Research 20(3): 205-212.

Dixit, Avinash K., and Robert S. Pindyck. 1994. "Investment Under Uncertainty." Princeton: Princeton University Press: 14-468.

Dollar, David, and Jakob Svensson. 2000. "What Explains the Success of Failure of Structural Adjustment Programmers." Economic Journal 110: 894-917.

Doucouliagos, H. and M. Paldam. 2008. "Aid effectiveness on growth: A meta-study." European Journal of Political Economy 24: 1 - 24.

Forbes, Kristin J. 2000. “A Reassessment of the Relationship between Inequality and Growth." American Economic Review 90: 869-887.

Easterly, William, Michael Kremer, Lant Pritchett, and Laurence Summers. 1993. "Good Policy or Good Luck? Country Performance and Temporary Shocks." Journal of Monetary Economics 32: 459-483. 
Easterly, William, and Ross Levine. 1997. “Africa’s Growth Tragedy: Policies and Ethnic Divisions.” Quarterly Journal of Economics 112: 1203-1250.

Easterly, William, and Sergio Rebelo. 1993. "Fiscal Policy and Economic Growth: An Empirical Investigation.” Journal of Monetary Economics 32: 417-458.

Hall, R., and Jones, C. 1999. "Why Do Some Countries Produce So Much More Output Per Worker Than Others?" The Quarterly Journal of Economics, MIT Press 114(1): 83 116.

Hall, Robert E., and Charles I. Jones. 1997. "Levels of Economic Activity Across Countries," American Economic Review, American Economic Association 87 (2): 17377.

Hillman, A. L. 2009. Public Finance and Public Policy: Responsibilities and Limitations of Government (2nd Ed.). Cambridge University Press, New York.

Hillman, A.L., and Konrad, K.A. 2008. Forty Years of Research on Rent Seeking, Volume II, Applications: Rent Seeking in Practice. Springer, Berlin: 245-264.

Hillman, A.L. 2004. "Nietzschean development failures.” Public Choice 119: 263-280.

Islam, Nazrul. 1995. “Growth Empirics: A Panel Data Approach.” The Quarterly Journal of Economics 110(4): 1127-1170.

Jong-A-Pin, R. 2009. “On the measurement of political instability andits impact on economic growth.” European Journal of Political Economy 25: 15-29.

Knack, Stephen, and Philip Keefer. 1995. "Institutions and Economic Performance: Cross-Country Tests Using Alternative Institutional Measures.” Economics and Politics 7: 207-227. 
Landau, Daniel. 1986. “Government and Economic Growth in the LDCs: An Empirical Study for 1960-1980.” Economic Development and Cultural Change 35: 35-76.

Levine, Ross, and David Renelt. 1992. “A Sensitivity Analysis of Cross-Country Growth Regressions." American Economic Review 82: 942-963.

Londregan, John B., and Keith Poole. 1990. "Poverty, the Coup Trap, and the Seizure of Executive Power." World Politics 42: 151-183.

Mankiw, N. Gregory, David Romer, D., and David N. Weil. 1992. "A Contribution to the Empirics of Economic Growth.” Quarterly Journal of Economics 107 (2): 407-438.

Mauro, P. 1995. “Corruption and Growth.” Quarterly Journal of Economics 110: 681712.

McCleary, Rachel M., and Barro, Robert J. 2006. "Religion and Economy.” Journal of Economic Perspectives 20 (2): 49-72.

Mehlum, H., Moene, K., and Torvik, R. 2006. "Institutions and the resource curse." Economic Journal 116: 1-20. Reprinted in: Congleton, R.D.,

Merrouche, O. 2008. "Landmines and Poverty: IV Evidence from Mozambique." Peace Economics, Peace Science and Public Policy 14, issue 1, article 2, http://www.bepress.com/peps/vol14/iss1/2.

Miguel, Edward, Shanker Satyanath, and Ernest Sergenti. 2003. "Economic Shocks and Civil Conflict: An Instrumental Variables Approach," Working Paper available at http://web.mit.edu/14.773/www/conflict_15apr03.pdf.

Montalvo, J., and Reynal-Querol, M. 2005. "Ethnic Polarization, Potential Conflict, and Civil Wars.” American Economic Review 95(3): 796-816.

Murdoch, James C., and Todd Sandler. 2002. "Economic Growth, Civil Wars, and

Spatial Spillovers.” Journal of Conflict Resolution 46(1): 91-110. 
Murdoch, James C., and Todd Sandler. 2004. "Civil Wars and Economic Growth: Spatial Dispersion.” American Journal Political Science 48(1): 138-151.

North, D. 1990. "Institutions, Institutional Change and Economic Performance." Cambridge University Press.

Parente, Stephen L., and Edward C. Prescott. 1994. "Barriers to Technology Adoption and Development.” Journal of Political Economy 102 (2): 298-321.

Persson, Torsten., and Lars E. Svensson. 1989. "Why a Stubborn Conservative Would Run a Deficit: Policy with Time Inconsistent Preferences.” Quarterly Journal of Economics 104: 325-245.

Persson, Torsten, and Guido Tabellini. 2006. "Democracy and Development: the Devil in the Details.” CESIFO Working Paper No.1672.

Polachek, Solomon W. 1980. "Conflict and Trade.” The Journal of Conflict Resolution 24 (1): 55-78.

Polachek, Solomon W. 1997. "Why Democracies Cooperate More and Fight Less: The Relationship between International Trade and Cooperation." Review of International Economics: 295-309.

Quah, Danny T. 1996. "Twin Peaks: Growth and Convergence in Models of Distribution Dynamics.” The Economic Journal 106(437): 1045-1055.

Romer, Paul M. 1990. “Endogenous Technological Change.” Journal of Political Economy 98 (5): S71-S102.

Richardson, L. F. 1960. Arms and Insecurity, A Mathematical Study of the Causes and Origins of War. The Boxwood Press, Pittsburgh and Quadrangle Books, Chicago. 
Sachs, Jeffrey D., and Andrew M. Warner. 1995. "Economic Reform and the Process of Global Integration.” Brookings Papers on Economic Activity Vol. 1995(1), 25 ${ }^{\text {th }}$ Anniversary Issue: 1-118.

Sachs, Jeffrey D., and Andrew M. Warner. 1997. "Fundamental Sources of Long-Run Growth." The American Economic Review 87(2), Papers and Proceedings of the Hundred and Fourth Annual Meeting of the American Economic Association (May, 1997): 184188.

Sachs, Jeffrey D., and Andrew M. Warner. 1997. "Natural Resource Abundance and Economic Growth.“ JEL Classification: O4, Q0, F43, November 1997. (Updated and extended version of the NBER Working Paper Series No. 5398, October 1995).

Sala-i-Martin, Xavier. 1996. "The Classical Approach to Convergence Analysis.” The Economic Journal 106: 1019-1036.

Sala-i-Martin, Xavier. 1997. “I Just Ran Two Million Regressions.” The American Economic Review 87(2), Papers and Proceedings of the Hundred and Fourth Annual Meeting of the American Economic Association (May, 1997): 178-183.

Sambanis, Nicholas. 2001. "Do Ethnic and Non-Ethnic Civil Wars Have the Same Causes? A Theoretical and Empirical Inquiry (Part 1)" Journal of Conflict Resolution 45(3): 259-282.

Seiglie, Carlos. 1992. "Determinants of military expenditures, in: W. Isard and C. Anderton, eds." Economics of Arms Reduction and the Peace Process, North-Holland, Amsterdam:183-202.

Solow, Robert M. 1957. "Technical Change and the Aggregate Production Function." Review of Economics and Statistics 39 (3): 312-320. 
Venieris, Yiannis. P., and Dipak K. Gupta. 1986. "Income Distribution and Sociopolitical Instability as Determinants of Savings: A Cross-sectional Model" Journal of Political Economy 94(4).

Wright, Q. 1942. A Study of War. University of Chicago Press, Chicago.

\section{Data References}

Central Intelligence Agency (CIA). 2007. CIA World Factbook 2007. http://www.cia.gov.

Ghosn, Faten, and Scott Bennett. 2003. "Codebook for the Dyadic Militarized Interstate Incident Data, Version 3.0.” http://cow2.la.psu.edu

Ghosn, Faten, Glenn Palmer, and Stuart A. Bremer. 2004. "The MID3 Data Set, 1993-2001: Procedures, Coding Rules, and Description." Conflict Management and Peace Science 21:133-154.

Goldstein, Joshua S. 1992. "A Conflict-Cooperation Scale for WEIS Events Data.” Journal of Conflict Resolution 36(2): 369-385.

Heston, Alan, Robert Summers, Bettina Aten. 2000. "Penn World Table Version 6.1." Center for International Comparisons at the University of Pennsylvania (CICUP).

Jones, Daniel M., Stuart A. Bremer, and J. David Singer. 1996 ."Militarized Interstate Disputes, 1816-1992: Rationale, Coding Rules, and Empirical Patterns." Conflict Management and Peace Science 15(2): 163-213. 
McClelland, Charles A. "WORLD EVENT/INTERACTION SURVEY (WEIS), 19661978." University of Southern California. 3rd ICPSR ed. Ann Arbor, MI: Inter-university Consortium for Political and Social Research [producer and distributor], 1999.

Pennsylvania State University. "Correlates of War Project (COW), Militarized Interstate Disputes 1979-1990(-2000).” http://www.cow.psu.edu

Pennsylvania State University. 2005. "State System Membership List, v2004.1." http://correlatesofwar.org.

Political Risk Services Group. 2007. “ICRG Data, IRIS diskette.” Bartle Library, Binghamton University.

Russett, Bruce M., J. David Singer, and Melvin Small, M. 1968. "National Political Units in the Twentieth Century: A Standardized List.” American Political Science Review 62(1): 932-951.

Sarkees, Meredith R. 2000. "The Correlates of War Data on War: An Update to 1997." Conflict Management and Peace Science 18/1: 123-144.

Singer, J. David, and Melvin Small. 1972. "Correlates of War Project:

International and Civil War Data, 1816-1992.” Ann Arbor, MI: ICPSR 9905.

Singer, J. David, and Melvin Small. 1972. "The Wages of War, 1816-1965: A

Statistical Handbook.” New York: John Wiley.

Singer, J. David, and Melvin Small. 1982. "Resort to Arms: International and Civil Wars, 1816-1980.” Beverly Hills, Calif.: Sage Publications.

Stockholm International Peace Research Institute. 2008. SIPRI Yearbook 2008.

http://yearbook2008.sipri.org/files/SIPRIYB08summary.pdf

The Nobel Prize Institute. 2008. Conflict Map. http://nobelprize.org/educational_games/peace/conflictmap/ and http://nobelprize.org/educational_games/peace/conflictmap/about.html 
World Bank. 2004. "World Development Indicators , CD-ROM." 


\section{Appendix A: Country Groups}

The aggregate sample of 123 countries was divided into shorter subsamples based on the criteria of geographic location, income level, and the style of government. Below are the complete lists of countries that fall within each category.

- OECD members (26 countries): Australia, Austria, Belgium, Canada, Switzerland, Germany, Denmark, Spain, Finland, France, Great Britain, Greece, Ireland, Iceland, Italy, Japan, Korea, Luxembourg, Mexico, the Netherlands, Norway, New Zealand, Portugal, Sweden, Turkey, USA.

- Latin America (24 countries): Argentina, Bolivia, Brazil, Barbados, Chile, Columbia, Costa Rica, Dominican Republic, Ecuador, Guatemala, Guyana, Honduras, Haiti, Jamaica, Mexico, Nicaragua, Panama, Peru, Paraguay, El Salvador, Suriname, Trinidad and Tobago, Uruguay, Venezuela.

- Africa (43 countries): Angola, Burundi, Benin, Burkina Faso, Botswana, Central Africa, Cote D'Ivoire, Cameroon, Congo, Algeria, Egypt, Ethiopia, Gabon, Ghana, Guinea, Gambia, Kenya, Liberia, Lesotho, Morocco, Madagascar, Mali, Mozambique, Mauritania, Mauritius, Malawi, Niger, Nigeria, Papua New Guinea, Rwanda, Sudan, Senegal, Sierra Leone, Somalia, Chad, Togo, Tunisia, Tanzania, Uganda, South Africa, Zaire, Zambia, Zimbabwe.

- OPEC members (10 countries): Algeria, Angola, Indonesia, Iran, Iraq, Kuwait, Nigeria, Saudi Arabia, United Arab Emirates, Venezuela.

- Asian Tigers (8 countries): Hong Kong, Indonesia, Japan, Korea, Malaysia, Singapore, Taiwan, Thailand.

- Democratic countries (62 countries assigned a score of 6 or above from the Polity IV project): Argentina, Australia, Austria, Belgium, Benin, Bangladesh, Bolivia, Brazil, Botswana, Canada, Switzerland, Chile, Colombia, Costa Rica, Cyprus, Germany, Denmark, Dominican Republic, Ecuador, Spain, Finland, France, Great Britain, Greece, Guatemala, Guyana, Hong Kong, Honduras, India, Ireland, Iceland, Israel, Italy, Jamaica, Japan, Luxembourg, Madagascar, Mexico, Mali, Malta, Mozambique, Mauritius, Malawi, Nicaragua, the Netherlands, Norway, New Zealand, Taiwan, 
Panama, Philippines, Papua New Guinea, Portugal, Paraguay, El Salvador, Sweden, Thailand, Trinidad and Tobago, Turkey, Uruguay, USA, Venezuela, South Africa.

- High-income countries (32 countries following the World Bank classification): United Arab Emirates, Australia, Austria, Belgium, Bahrain, Canada, Switzerland, Cyprus, Germany, Denmark, Spain, Finland, France, Great Britain, Greece, Hong Kong, Ireland, Iceland, Italy, Israel, Japan, Kuwait, Luxembourg, Malta, the Netherlands, Norway, New Zealand, Portugal, Saudi Arabia, Singapore, Sweden, USA.

- Lower and upper middle-income countries (49 countries): Angola, Argentina, Bolivia, Brazil, Barbados, Botswana, Chile, China, Cameroon, Colombia, Costa Rica, Dominican Republic, Algeria, Ecuador, Egypt, Fiji, Gabon, Guatemala, Guyana, Honduras, Indonesia, Iran, Iraq, Jamaica, Jordan, Sri Lanka, Lesotho, Morocco, Mexico, Mauritius, Malaysia, Nicaragua, Oman, Taiwan, Panama, Peru, Philippines, Paraguay, El Salvador, Suriname, Swaziland, Syria, Thailand, Trinidad and Tobago, Tunisia, Turkey, Uruguay, Venezuela, South Africa.

- Low-income countries (41 countries): Afghanistan, Burundi, Benin, Burkina Faso, Bangladesh, Myanmar, Central Africa, Cote D'Ivoire, Congo, Ethiopia, Ghana, Guinea, Gambia, Haiti, India, Kenya, Korea, Liberia, Madagascar, Mali, Mozambique, Mauritania, Malawi, Niger, Nigeria, Nepal, Pakistan, Papua New Guinea, Rwanda, Sudan, Senegal, Sierra Leone, Somalia, Chad, Togo, Tanzania, Uganda, Yemen, Zaire, Zambia, Zimbabwe. 